Engineering Technology Division

\title{
FEDERAL METHANOL FLEET PROJECT FINAL REPORT
}

\author{
B. H. West \\ R. N. McGill \\ S. L. Hillis* \\ J. W. Hodgson* \\ University of Tennessee
}

Date Published: March 1993

Prepared for the

Office of Transportation Systems

EE5001

Prepared by the

OAK RIDGE NATIONAL LABORATORY

Oak Ridge, Tennessee 37831-6285

managed by

MARTIN MARIETTA ENERGY SYSTEMS, INC.

for the

U.S. DEPARTMENT OF ENERGY

MASTER

under Contract No. DE-ACO5-84OR21400 


\section{CONTENTS}

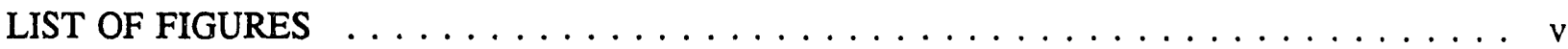

LIST OF TABLES $\ldots \ldots \ldots \ldots \ldots \ldots \ldots \ldots \ldots \ldots \ldots \ldots \ldots \ldots \ldots$

ABSTRACT $\ldots \ldots \ldots \ldots \ldots \ldots \ldots \ldots \ldots \ldots \ldots \ldots \ldots \ldots \ldots \ldots$

PREFACE $\ldots \ldots \ldots \ldots \ldots \ldots \ldots \ldots \ldots \ldots \ldots \ldots \ldots \ldots \ldots \ldots \ldots \ldots$

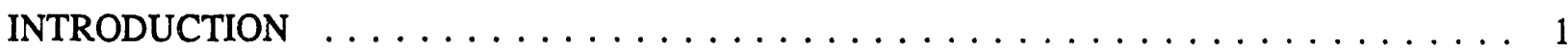

LAWRENCE BERKELEY LABORATORY FLEET $\ldots \ldots \ldots \ldots \ldots \ldots \ldots \ldots$

ARGONNE NATIONAL LABORATORY FLEET $\ldots \ldots \ldots \ldots \ldots \ldots \ldots \ldots \ldots \ldots$

OAK RIDGE NATIONAL LABORATORY FLEET $\ldots \ldots \ldots \ldots \ldots \ldots \ldots \ldots \ldots$

FINDINGS AND OBSERVATIONS $\ldots \ldots \ldots \ldots \ldots \ldots \ldots \ldots \ldots \ldots$

FLEET UTILIZATION AND FUEL CONSUMPTION $\ldots \ldots \ldots \ldots \ldots \ldots \ldots \ldots \ldots$

EMISSIONS TESTS $\ldots \ldots \ldots \ldots \ldots \ldots \ldots \ldots \ldots \ldots \ldots \ldots$

Background ........................ 4

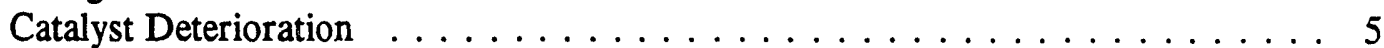

ENGINE OIL ANALYSIS $\ldots \ldots \ldots \ldots \ldots \ldots \ldots \ldots \ldots \ldots$

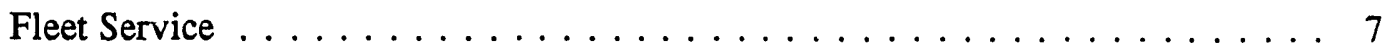

Short-Trip Testing . . . . . . . . . . . . . . . . . . . . . . 10

COMPARISON OF MAINTENANCE AND SERVICE $\ldots \ldots \ldots \ldots \ldots \ldots \ldots \ldots$

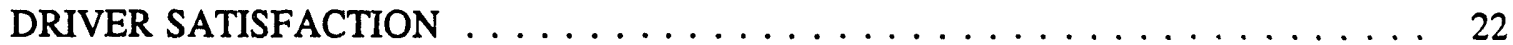

Response From Driver Logs $\ldots \ldots \ldots \ldots$. . . . . . . . . . . . . 22

Response From Driver Surveys $\ldots \ldots \ldots \ldots$

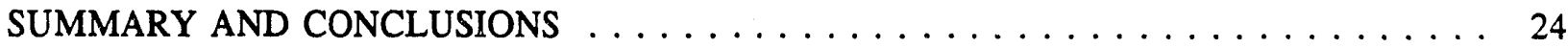

ACKNOWLEDGMENTS $\ldots \ldots \ldots \ldots \ldots \ldots \ldots \ldots \ldots \ldots \ldots \ldots \ldots$

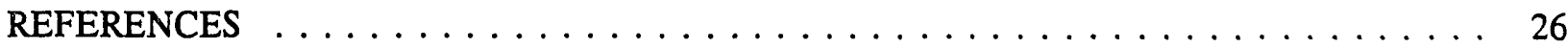

ACRONYMS AND NOMENCLATURE $\ldots \ldots \ldots \ldots \ldots \ldots \ldots \ldots \ldots \ldots$ 


\section{LIST OF FIGURES}

Figure 1. Iron accumulation rate in ORNL Buicks as a function of quarter. . . . . . . 7

Figure 2. Iron accumulation rate in LBL Chevrolet Citations as a function of quarter. $\ldots \ldots 8$

Figure 3. Iron accumulation rate in ANL Chevrolets as a function of season. $\ldots \ldots \ldots$

Figure 4. Iron accumulation rate in ANL Fords as a function of season. $\ldots \ldots \ldots$

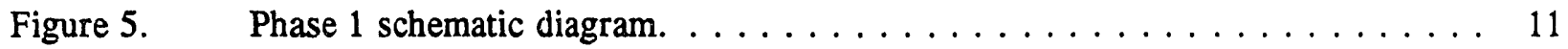

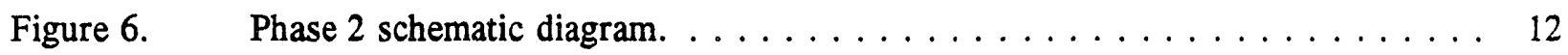

Figure 7. Methanol and gasoline vehicle oil and coolant temperatures for a typical short-trip. 14

Figure 8. Phase 1 ambient and oil temperatures for both vehicles. $\ldots \ldots \ldots 15$

Figure 9. Phase 1 total volatile contamination in oil for both vehicles. . . . . . 15

Figure 10. Phase 1 fuel and water dilution in methanol vehicle's oil. $\ldots \ldots \ldots \ldots$

Figure 11. Phase 1 fuel and water dilution in gasoline vehicle's oil. $\ldots \ldots \ldots \ldots$

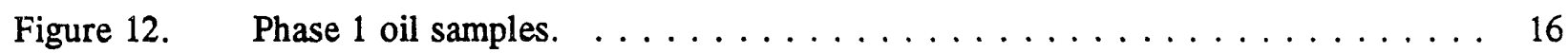

Figure 13. Phase 1 total base number for both vehicles. $\ldots \ldots \ldots \ldots \ldots$

Figure 14. Phase 1 iron concentrations in both vehicles' oil. . . . . . . . . . . 17

Figure 15. Phase 2 ambient and oil temperatures for both vehicles. $\ldots \ldots \ldots \ldots$

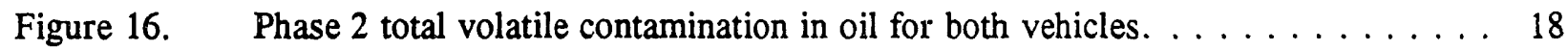

Figure 17. Phase 2 fuel and water dilution in methanol vehicle's oil. $\ldots \ldots \ldots \ldots$

Figure 18. Phase 2 fuel and water dilution in gasoline vehicle's oil. . . . . . . . . . . 19

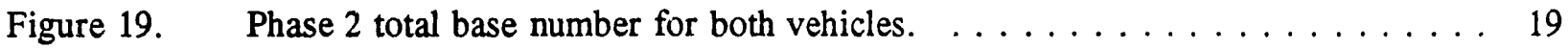

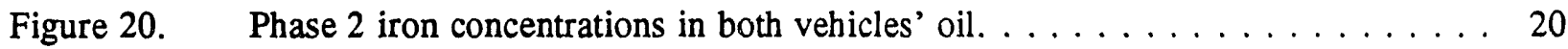

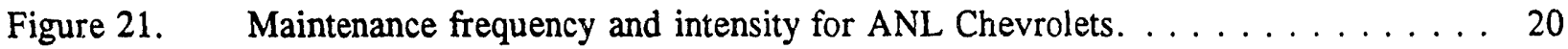

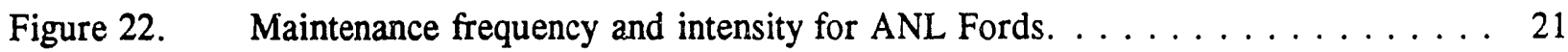

Figure 23. Maintenance frequency and intensity for ORNL Buicks. $\ldots \ldots \ldots \ldots$ 
Figure 24. Maintenance frequency and intensity for LBL Chevrolet Citations. . . . . . . 22

Figure 25. Average ease of starting ratings for first daily start as a function of month. . . . 22 


\section{LIST OF TABLES}

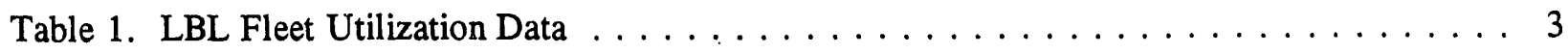

Table 2. ANL Fleet Utilization Data for Chevrolets $\ldots \ldots \ldots \ldots \ldots$

Table 3. ANL Fleet Utilization Data for Fords $\ldots \ldots \ldots \ldots \ldots$

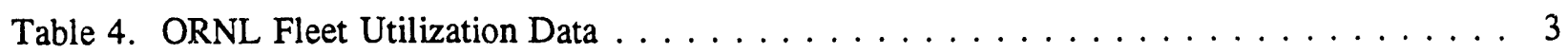

Table 5. Laboratories Used for Emissions Testing $\ldots \ldots \ldots \ldots \ldots$

Table 6. Emissions From Chevrolet Citation $754 \ldots \ldots \ldots \ldots \ldots$

Table 7. Emissions From Chevrolet Citation $753 \ldots \ldots \ldots \ldots \ldots$

Table 8. Emissions from Ford Crown Victorias $\ldots \ldots \ldots \ldots \ldots$

Table 9. Emissions From Buick Regal $9394 \ldots \ldots \ldots \ldots \ldots$

Table 10. Oil Formulation Used in Methanol Vehicles at ORNL $\ldots \ldots \ldots \ldots$

Table 11. Methods used in oil analysis $\ldots \ldots \ldots \ldots \ldots \ldots \ldots \ldots \ldots \ldots \ldots$

Table 12. Analysis results for fresh, pre-aged, and test vehicle oil samples before and after oil

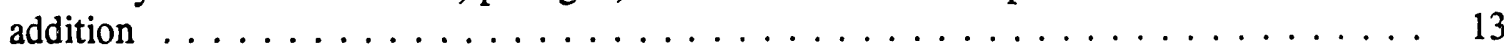




\begin{abstract}
The Federal Methanol Fleet Project concluded with the termination of data collection from the three fleet sites in February 1991. The Lawrence Berkeley Laboratory (LBL) completed five years of operation, Argonne National Laboratory (ANL) completed its fourth year in the project, and Oak Ridge National Laboratory (ORNL) completed its third. Twenty of the thirty-nine vehicles in the fleet were powered by fuel methanol (typically M85, 85\% methanol, $15 \%$ unleaded gasoline, although the LBL fleet used M88), and the remaining control vehicles were comparable gasoline vehicles. Over 2.2 million $\mathrm{km}$ (1.4 million miles) were accumulated on the fleet vehicles in routine government service. Data collected over the years have included vehicle mileage and fuel economy, engine oil analysis, emissions, vehicle maintenance, and driver acceptance.

Fuel economies (on an energy basis) of the methanol and gasoline vehicles of the same type were comparable throughout the fleet testing. Engine oil analysis has revealed higher accumulation rates of iron and other metals in the oil of the methanol vehicles, although no significant engine damage has been attributed to the higher metal content. Vehicles of both fuel types have experienced degradation in their emission control systems, however, the methanol vehicles seem to have degraded their catalytic converters at a higher rate. The methanol vehicles have required more maintenance than their gasoline counterparts, in most cases, although the higher levels of maintenance cannot be attributed to "fuel-related" repairs. According to the daily driver logs and results from several surveys, drivers of the fleet vehicles at all three sites were generally satisfied with the methanol vehicles.
\end{abstract}




\section{PREFACE}

This report is the last in a series of yearly reports on the results from the Federal Methanol Fleet project. Each of the nine previous reports details the annual results from one of the three fleet sites. This final report is somewhat brief, therefore readers are encouraged to refer to the previous nine reports for rigorous details. All of these other reports in the series should be referred to in order to benefit from the entire context of the project, and to avoid the risk of possibly misreading limited results from only one report.

A brief review of some of the philosophies and practices implemented in this project are presented below in order to further reduce the possibility of data being taken out of context.

* This project resulted from a congressional appropriation in Fiscal Year 1985 and the associated mandate to begin to place methanol-fueled vehicles into government fleets and assess their performance. Funds for these purposes have totalled approximately $\$ 2.4$ million through Fiscal Year 1992.

* It was decided to use the best available "proven" technology for converting vehicles to methanol since it was impossible in 1985 to obtain methanol vehicles from original equipment manufacturers (OEMs). The intent was to acquire methanol converted vehicles from as many "proven" aftermarket companies as funds would permit ("proven" meaning that the aftermarket company possessed a demonstrated record of successful conversions of gasoline vehicles to methanol).

* It was decided to operate the methanol vehicles in all cases alongside baseline gasoline vehicles for comparison. This required the acquisition of the gasoline vehicles also.

* While it was desirable to achieve the lowest possible emissions with the converted methanol vehicles, it was recognized that this would be an expensive proposition because rigorous engineering and development would be necessary in order to accomplish this goal. Because of this, the methanol vehicles were not optimized for lowest emissions. Instead, the philosophy was to acquire the vehicles, measure their emissions, and track their performance over time. The important comparison would be how emissions change over time and not how they would compare to the lowest attainable. Emissions measured immediately after methanol conversions would serve as the baseline for comparison.

* All the vehicles in the project were to be used in routine fleet service within the organizations to which they were to be assigned. This limited the extent to which very specialized tests or driving cycles could be utilized. On the other hand, the vehicles would experience a "real-world" environment, and it is within that context that they have been evaluated. 


\title{
FEDERAL METHANOL FLEET PROJECT \\ FINAL REPORT
}

\author{
B. H. West \\ R. N. McGill \\ S. L. Hillis \\ J. W. Hodgson
}

\section{INTRODUCTION}

The Federal Methanol Fleet (FMF) was a Congressionally mandated program initiated in 1985 to place methanol vehicles into routine government service. Oak Ridge National Laboratory (ORNL) has had project management responsibility for the project and has collected and disseminated data from all three fleet sites. The three sites are the Lawrence Berkeley Laboratory (LBL), the Argonne National Laboratory (ANL), and the Oak Ridge National Laboratory (ORNL). Over the past six years, nine reports $(1-9)^{*}$ have detailed the fleet operation and results. This final summary report will be somewhat brief, and will focus mainly on results. The reader is encouraged to refer to the earlier reports for more detail. Short descriptions of the individual fleets are presented below.

\section{LAWRENCE BERKELEY LABORATORY FLEET}

The LBL fleet was the first pressed into operation in the spring of 1985 with the methanol conversion of five relatively new 1984 Chevrolet Citations with carburetted $2.8 \mathrm{~L} \mathrm{~V}-6$ engines. The conversion was performed by the Bank of America, in the San Francisco, California area. The Bank of America had previously performed conversions on

"Numbers in parentheses denote references at the end of the report. similar cars for their own use. The conversion essentially consisted of replacing components which were not methanol compatible, and changing the air/fuel ratio via carburetor alterations (the stock compression ratio was maintained). A more detailed description of the LBL conversion can be found in Reference 1.

The five gasoline control vehicles were comparable 1984 Citations commandeered from the central motor pool. These vehicles had each accumulated roughly $32-48,000 \mathrm{~km} \quad(20-30,000$ miles) in government service before being assigned to the FMF. All the FMF vehicles were used for transportation around the LBL site, into and around Berkeley and Oakland, and to and from Lawrence Livermore Laboratory or the Stanford Linear Accelerator Center iri Palo Alto. The fuel used at LBL was nominally M88 (88 volume \% methanol, $12 \%$ unleaded gasoline), although it was varied seasonally between M86 and M90. A refueling tank was installed on-site at the LBL motor pool area. Commercial refueling sites were also available to the drivers in the Bay area, many of which provided the more common M85 blend.

\section{ARGONNE NATIONAL LABORATORY FLEET}

Ten vehicles were converted to M85 operation in the late fall of 1986 for the ANL fleet. Five 1986 Ford Crown Victoria security vehicles with port fuel injected 5.0L V-8 engines, and five 
1986 Chevrolet S-10 pickup trucks with throttlebody injected $2.5 \mathrm{~L}$ four cylinder engines were converted by Alcohol Energy Systems, Inc. of Santa Clara, California. The control vehicles at ANL consisted of four similar gasoline Fords and five similar gasoline Chevrolets. The total fleet, therefore, consisted of nineteen vehicles. An M85 refueling tank and dispensing pump were installed at the ANL refueling site. This was the only place that the methanol vehicles were refueled.

The Argonne site, near Chicago, was chosen as the cold-weather test site for the Federal Methanol Fleet, and the methanol vehicles assigned there were equipped with special cold-start systems. The system on the Chevrolets started the engine on gasoline (from a separate auxiliary fuel tank) when the coolant temperature was below $0^{\circ} \mathrm{C}\left(32^{\circ} \mathrm{F}\right)$, and would automatically switch over to methanol fuel operation after about 30 seconds. The system on the Fords used only the methanol fuel, was provided by Ford, and is proprietary and cannot be discussed in detail. All nineteen vehicles were also equipped with block heaters for use in extremely cold weather. The conversions of the ANL vehicles involved not only replacing non-methanol compatible components and adjustment of air/fuel ratios, but also installation of the cold-start systems and high compression pistons. The Chevrolets' compression ratios were increased from 9.0 to 10.5 , and the Fords' from 9.2 to 11.2. (A more detailed discussion of the ANL conversions can be found in Reference 5.)

\section{OAK RIDGE NATIONAL LABORATORY FLEET}

Data collection for the ORNi fleet began with the receipt of five 1987 gasoline powered 3.8L turbo Buick Regals in the summer of 1987. Five similar cars were converted to M85 operation by the Michigan Automotive Research Corporation, in Ann Arbor, Michigan, and were received in Oak Ridge in the late fall of 1987. The methanol conversion involved replacement of non-methanol compatible components, and changes to the engine control module (ECM) and other hardware to obtain the proper air/fuel ratio. Except for a minor spark timing adjustment by the ECM at cold-start, the methanol Buicks had no special cold-start systems. The conversion is discussed in detail in Reference \&.

The Buicks at ORNL were used for routine fleet service in and around the three DOE sites in Oak Ridge, Tennessee. An M85 refueling tank was located at one of the three sites, and was the only place that the methanol vehicles could be refueled, although on a few occasions, methanol fuel drums were shipped to strategic locations to allow longer highway trips.

\section{FINDINGS AND OBSERVATIONS}

\section{FLEET UTILIZATION AND FUEL CONSUMPTION}

Tables 1 through 4 show the mileage accumulation, average trip mileage, and fuel economy for the aggregates of each vehicle type from each of the three fleets over the course of the project. The LBL Chevrolet data are given in Table 1, the ANL Chevrolet and Ford data in Tables 2 and 3 , respectively, and the ORNL Buick data in Table 4. Note in Tables 2 and 3 that the average trip lengths for the methanol and gasoline vehicles were very nearly the same (for both the Chevrolets and the Fords) at ANL and, as such, the fuel economies (on an energy basis) were also very comparable. This results from the fact that the gasoline and methanol vehicles of each type were used in nearly identical service. While the higher compression ratios in the methanol vehicles would be expected to contribute to improved fuel economy, there is little or no apparent improvement. Reasons for this disparity are not clear. The LBL methanol Chevrolets, on the other hand, suffered a 17 percent lower fuel economy than their gasoline counterparts. 


\begin{tabular}{|c|c|c|c|c|}
\hline \multicolumn{5}{|c|}{$\begin{array}{l}\text { Table 1. LBL Fleet Utilization Data } \\
\text { Summary of five years } \\
\text { Chevrolet Citations }\end{array}$} \\
\hline & \multirow[b]{2}{*}{$\begin{array}{l}\text { Total } \\
\text { miles }\end{array}$} & \multirow[b]{2}{*}{$\begin{array}{l}\text { Averafe } \\
\text { milestroip }\end{array}$} & \multicolumn{2}{|c|}{ Fud coononyy } \\
\hline & & & $m p g$ & $k m / G b^{b c}$ \\
\hline \multicolumn{5}{|c|}{ Methanol vehicles } \\
\hline Ist year & 36,864 & 36 & 11.4 & 274 \\
\hline 2nd year & 35.958 & 38 & 11.7 & 281 \\
\hline 3rd year & 30,440 & 38 & 10.9 & 260 \\
\hline 4h year & 25,388 & 31 & 11.2 & 269 \\
\hline Sth year & 15,062 & 23 & 9.9 & 238 \\
\hline All years & 143,712 & 34 & 11.1 & 267 \\
\hline \multicolumn{5}{|c|}{ Gasoline vehicles } \\
\hline Ist year & 74,329 & 57 & 24.1 & 318 \\
\hline 2nd year & 63,812 & 46 & 24.9 & 329 \\
\hline 3rd year & 43.057 & 38 & 21.5 & 234 \\
\hline 4th year & $\begin{array}{l}\text { Not in } \\
\text { service }\end{array}$ & & & \\
\hline Sth year & $\begin{array}{l}\text { Not in } \\
\text { service }\end{array}$ & & & \\
\hline All years & 181,198 & 48 & 23.6 & 312 \\
\hline
\end{tabular}

${ }^{2}$ To conver miles to $\mathrm{km}$, multiply by 1.609

based on total quantities for five vehicles.

${ }^{C_{B}}$ ased on metha nol lower heating value of $56,560 \mathrm{Btw} / \mathrm{gal}$ and gasoline lower heating value of $115,400 \mathrm{Btw} / \mathrm{gal} ; \mathrm{M} 88$ lower heating value equals $63,620 \mathrm{Btu} / \mathrm{gal}\left(17.73 \mathrm{GJ} / \mathrm{m}^{3}\right)$.

\begin{tabular}{|c|c|c|c|c|}
\hline \multicolumn{5}{|c|}{$\begin{array}{c}\text { Table 2. ANL Fleet Utilization Data for Chevrolets } \\
\text { Summary of four years }\end{array}$} \\
\hline & \multirow[b]{2}{*}{$\begin{array}{l}\text { Toenl } \\
\text { miles }\end{array}$} & \multirow[b]{2}{*}{$\begin{array}{l}\text { Average } \\
\text { mila/trip }\end{array}$} & \multicolumn{2}{|c|}{ Fued 0000000} \\
\hline & & & $\mathrm{mpg}$ & $\ln / G^{b c}$ \\
\hline \multicolumn{5}{|c|}{ Methanol vehicle } \\
\hline 1st year & 43.035 & 16 & 9.6 & 224 \\
\hline 2nd year & 30.550 & 19 & 9.0 & 211 \\
\hline 3rd year & 32009 & 17 & 9.0 & 211 \\
\hline 4th year & 30,825 & 16 & 8.6 & 201 \\
\hline All years & 136.419 & 17 & 9.1 & 211 \\
\hline \multicolumn{5}{|c|}{ Grooline vehicles } \\
\hline 1st year & 46,426 & 16 & 16.9 & 219 \\
\hline 2nd year & 35,944 & 18 & 17.2 & 227 \\
\hline 3rd year & 35.186 & 15 & 16.4 & 216 \\
\hline 4th year & 38.265 & 18 & 14.3 & 189 \\
\hline All years & 155,821 & 16 & 16.0 & 212 \\
\hline
\end{tabular}

To convert miles to km, multiply by 1.609

b Based on total quantities for five vehicles.

${ }^{\mathrm{C}}$ Based on methanol lower heating value of $56.560 \mathrm{Btw} / \mathrm{gal}$ and gasoline lower beating value of $115,400 \mathrm{Btw} / \mathrm{gal} ; \mathrm{M} 85$ lower heating value equals $65,390 \mathrm{Btu} / \mathrm{gal}\left(1822 \mathrm{GJ} / \mathrm{m}^{3}\right)$.

\begin{tabular}{|c|c|c|c|c|}
\hline \multicolumn{5}{|c|}{$\begin{array}{l}\text { Table 3. ANL Fleet Utilization Data for Fords } \\
\text { Summary of four years }\end{array}$} \\
\hline & \multirow{2}{*}{$\begin{array}{l}\text { Total } \\
\text { miles }\end{array}$} & \multirow{2}{*}{$\begin{array}{l}\text { Average } \\
\text { milestrip }\end{array}$} & \multicolumn{2}{|c|}{ Fued coonouns } \\
\hline & & & mpg & $\ln / \mathbf{a j}^{b c}$ \\
\hline \multicolumn{5}{|c|}{ Methanol vehicles } \\
\hline Ist year & 97.389 & 11 & 6.2 & 145 \\
\hline 2nd year & 75.915 & 28 & 6.2 & 145 \\
\hline 3 rd year & 63.034 & 28 & 6.1 & 143 \\
\hline 4th year & 70.191 & 56 & 5.6 & 130 \\
\hline All vears & 306.529 & 20 & 6.0 & 140 \\
\hline \multicolumn{5}{|c|}{ Gesoline vehicien } \\
\hline 1st year & 114,496 & 11 & 10.5 & 139 \\
\hline 2nd year & 57.274 & 25 & 10.5 & 139 \\
\hline 3rd year & 42.734 & 30 & 10.4 & 138 \\
\hline 4 th year & 58.148 & 49 & 9.5 & 126 \\
\hline All years & 272652 & 17 & 10.2 & 135 \\
\hline
\end{tabular}

To convert miles to km. multiply by 1.609

bBased on total quantities for five methanol vebicles. four gasoline vehicles.

${ }^{C}$ Based on methanol lower beating value of $56.560 \mathrm{Btu} / \mathrm{gal}$ and gasoline lower beating value of $115,400 \mathrm{Btu} / \mathrm{gal}$ : M85 lower heating value equals $65.390 \mathrm{Btw} / \mathrm{gal}\left(18.22 \mathrm{GJ} / \mathrm{m}^{3}\right)$.

\begin{tabular}{|c|c|c|c|c|}
\hline \multicolumn{5}{|c|}{$\begin{array}{l}\text { Table 4. ORNL Fleet Utilization Data } \\
\text { Summary of three years }\end{array}$} \\
\hline & \multirow[b]{2}{*}{$\begin{array}{l}\text { Total } \\
\text { mite }\end{array}$} & \multirow[b]{2}{*}{$\begin{array}{l}\text { Average } \\
\text { mileatrip }\end{array}$} & \multicolumn{2}{|c|}{ Fued $00000 \mathrm{~ms}$} \\
\hline & & & $m p g^{b}$ & $\operatorname{lom} / G^{b c}$ \\
\hline \multicolumn{5}{|c|}{ Methanol vehicle } \\
\hline Ist year & 31.681 & 11 & 9.8 & 224 \\
\hline 2nd year & 25.133 & 9 & 9.5 & 222 \\
\hline 3 rd vear & 24.305 & 10 & 9.1 & 213 \\
\hline All years & 81.119 & 10 & 9.5 & 222 \\
\hline \multicolumn{5}{|c|}{ Gasoline vehicle } \\
\hline 1st year & 64.480 & 18 & 19.1 & 253 \\
\hline 2nd year & 31.509 & 15 & 17.5 & 232 \\
\hline 3 rd year & 31.715 & 12 & 17.5 & 232 \\
\hline All years & 127.704 & 16 & 18.3 & 242 \\
\hline
\end{tabular}

${ }^{2}$ To convert miles to km. multiply by 1.609

b Based on total quantities for five vehicles.

$\mathrm{C}_{\text {Based on methanol lower beating value of } 56.560 \mathrm{Btu} / \mathrm{gal} \text { and }}$ gasoline lower heating value of $115,400 \mathrm{Btw} / \mathrm{gal}$ : M85 lower beating value equals $65.390 \mathrm{Btu} / \mathrm{gal}\left(18.22 \mathrm{GJ}^{3}{ }^{3}\right)$. 
This lower fuel economy can probably be attributed to the longer average trip lengths of the gasoline cars. Albeit to a lesser extent, a similar observation can be made regarding the Buicks at ORNL as shown in Table 4.

\section{EMISSIONS TESTS}

\section{Background}

As stated in the Preface, the goal of the FMF Project was not necessarily to produce low emission methanol vehicles. The methanol vehicles used in the project were retrofitted, and it was realized that a tremendous amount of engineering would be required to achieve low emissions. As a result, it was decided to measure the vehicles' emissions soon after conversion to methanol, and then track their performance over time. Again, full details have been provided in previous reports $(1,3,5-8)$, and only highlights will be presented here.

The OEM emission control system components (EGR valves, catalysts, fuel vapor recovery systems, etc.) remained intact on all of the converted methanol vehicles. However, mechanical changes (increased compression ratios, larger injectors, larger carburetor jets) and engine control system changes (revised EGR schedules, spark timing revisions, injector pulse width revisions) were made and would be expected to influence the emissions. Since emission reduction was not the focus of the fleet operation, converted vehicles, in some cases, had higher emissions after conversion than before. The emission values reported should not be taken as being representative of what should be expected from methanol-fueled vehicles that are converted or manufactured with emissions as an important conversion parameter. In fact, vehicles converted to M85 use by engineering students in competitions have achieved emissions well below the applicable EPA limits (10-12). Also, OEMs are currently manufacturing flexible or variable-fuelvehicles (FFVs, VFVs), which are meeting all applicable standards. The authors believe that the
FMF emissions reported can be useful in terms of changes in emission levels that may arise as vehicles accumulate service time and mileage. In at least two cases, interesting comparisons between methanol and gasoline catalyst deterioration have resulted from the test program.

During the period of this demonstration project, emission testing of methanol-fueled vehicles was a developing technology. As a result, testing procedures used during the fleet program were not consistent as the program progressed. In particular, techniques for measuring the aldehydes, the unburned methanol, and the other organic gases in the exhaust were in a state of flux. This is associated with the fact that the flame ionization detector (FID) typically used to measure unburned hydrocarbons from gasoline-fueled vehicles has essentially no response to aldehydes and only partial response to unburned methanol. In addition, even when a procedure was developed for handling these exhaust constituents, the emission testing laboratory doing the tests might not have been equipped to conduct the testing according to procedures recommended by the Environmental Protection Agency (EPA) (13). Fortunately, the impact of the FID response is negligible in terms of the $\mathrm{CO}$ (carbon monoxide) and $\mathrm{NO}_{\mathbf{x}}$ (oxides of nitrogen) measurements, so these quantities can be reported with a high degree of confidence. The organic gases in the exhaust have been reported as OMHCE (Organic Material Hydrocarbon Equivalent) - defined by the EPA (13). In order to report the OMHCE in situations where direct measurements of the methanol in the exhaust were not made, a method of estimating the OMHCE (the ORNL protocol) was developed and appears to give satisfactory agreement with OMHCE values derived from actual methanol measurements (6).

Because the three fleet locations were widely scattered and because the vehicle conversions were conducted by a variety of contractors, several different laboratories were used for the emissions tests, as shown in Table 5. Since the results of the 


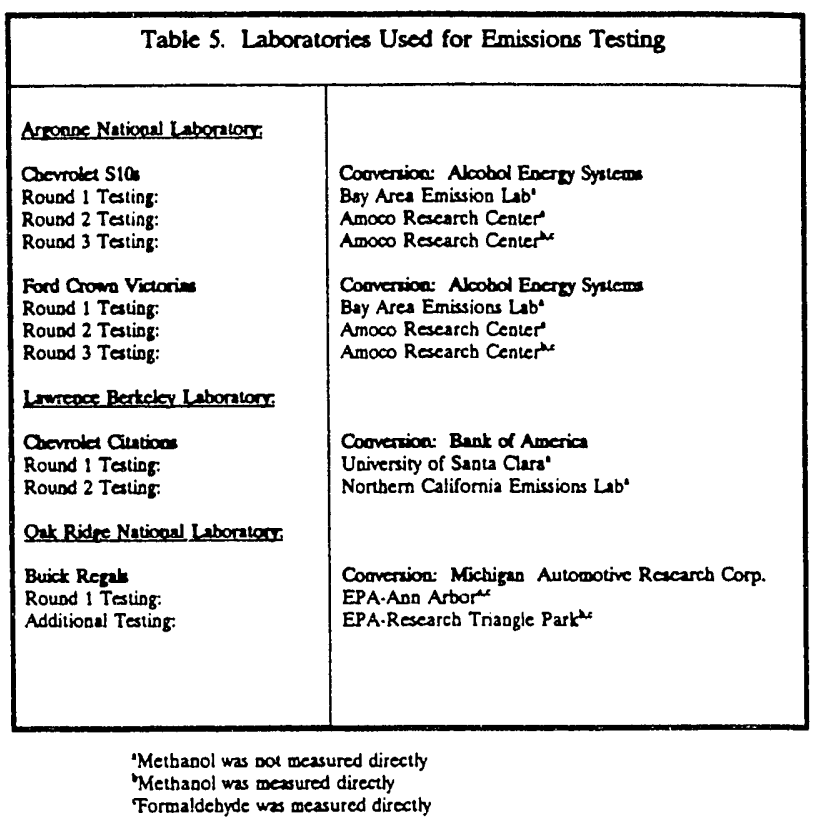

individual tests have been reported elsewhere $(1,3,5$ $8)$, they will not all be repeated here. The intent is to highlight what are considered to be some of the more interesting findings from the data.

\section{Catalyst Deterioration}

All the converted vehicles retained the OEM catalysts which were, of course, designed for service on vehicles fueled with gasoline. It is important to note that catalyst suppliers would probably recommend using catalysts tailored specifically for methanol on these vehicles. Nevertheless, it is worthwhile to examine some of the emissions results obtained from this program.

Chevrolet Citations - Two of the Citations at Lawrence Berkeley Laboratory were tested for emissions after accumulating over $32,000 \mathrm{~km}$ (20,000 miles) of service on methanol. Vehicle 754 was tested three times to check the consistency of the testing, and then tested again after having the catalyst replaced. The results are shown in Table 6 . A similar procedure was used on vehicle 753 with the exception that no repeatability tests were conducted. The results are shown in Table 7.

\begin{tabular}{|c|c|c|c|c|}
\hline \multicolumn{4}{|c|}{ Table 6. Emissions From Chevrolet Citation 754 } \\
\hline $\begin{array}{c}\text { Odometer } \\
\text { (miles) }\end{array}$ & Condition & \multicolumn{3}{|c|}{ FTP Emissions (g/mile) } \\
\hline 1,669 & Initial Test & 2.38 & 0.59 & 1.06 \\
\hline 28,110 & After Tune-up & 2.88 & 0.27 & 1.16 \\
\hline 28,623 & Re-test & 1.71 & 0.23 & 1.16 \\
\hline 28,642 & Re-test & 2.38 & 0.23 & 1.13 \\
\hline 28,858 & New Catalyst & 1.39 & 0.12 & 1.00 \\
\hline
\end{tabular}

"To convert miles to $\mathrm{km}$, multiply by 1.609

\begin{tabular}{|c|c|c|c|c|}
\hline \multicolumn{5}{|c|}{ Table 7. Emissions From Chevrolet Citation 753 } \\
\hline $\begin{array}{c}\text { Odometer } \\
\text { (miles) }\end{array}$ & Condition & \multicolumn{3}{|c|}{ FTP Emissions (g/mile) } \\
\hline 1,475 & Initial Test & 1.87 & 0.98 & 0.66 \\
\hline 23,344 & After Tune-up & 1.88 & 0.24 & 1.06 \\
\hline 24,152 & New Catalyst & 0.84 & 0.16 & 0.81 \\
\hline
\end{tabular}

${ }^{\circ}$ To convert miles to $\mathrm{km}$, multiply by 1.609

The )MHCE and $\mathrm{NO}_{x}$ values for vehicle 754 (Table 6) were fairly repeatable, but the $\mathrm{CO}$ data were not. The initial tests on both vehicles were conducted at a test facility different from the one used for the later tests. Comparing the initial test values with those from later tests raises the possibility that the effects observed may have been associated with the testing facility rather than the vehicle condition. On the other hand, comparing the data before and after the installation of a replacement catalyst raises the possibility that the replacement catalyst was inherently more effective than the original catalyst.

If one accepts the premise that there was no effect associated with testing at different facilities, then the catalysts showed no appreciable change in CO conversion efficiency, an increase in the OMHCE conversion efficiency, and a slight loss in the $\mathrm{NO}_{\mathrm{x}}$ conversion efficiency. Comparing the results from the same laboratory for the used and the new catalysts would indicate increased efficiency for the new catalyst over the old one with the possible inference that the catalyst had deteriorated with use. In either case, however, the deterioration was not severe and the results from the Citation tests do not 
suggest a major problem with the catalysts within the use patterns experienced by these vehicles.

Ford Crown Victorias - The final round of emission testing conducted on the ANL Fords led to some very interesting results. A methanol vehicle was tested with its original catalyst (a re-test was conducted to get some indication of repeatability) along with a gasoline Ford Crown Victoria (which was not part of the FMF). The catalysts from the two vehicles were then switched and another test run on each vehicle. The results are shown in Table 8. Formaldehyde ( $\mathrm{HCOH})$ emissions were measured directly and are also shown in this table.

\begin{tabular}{|c|c|c|c|c|c|}
\hline $\begin{array}{l}\text { Odometer } \\
\text { (miles)" }\end{array}$ & Coodition & $\infty$ & $\begin{array}{l}\text { FTP Em } \\
\text { UMHCEE }\end{array}$ & $\begin{array}{l}\text { (s)mile) } \\
\mathrm{NO}_{\mathrm{s}}\end{array}$ & $\mathrm{HCOH}$ \\
\hline \multicolumn{6}{|c|}{ Mathaool vebicte } \\
\hline 53,300 & Original Catayst & 239 & 0.63 & 0.45 & 0.312 \\
\hline 53,300 & Re-lest & 235 & 0.66 & 0.43 & 0.299 \\
\hline 58.400 & Gasolixe Catalyat & 0.76 & 0.27 & ก.37 & 0.060 \\
\hline \multicolumn{6}{|c|}{ Gesoline veluide } \\
\hline 40,200 & Drigios Causyst & 1.34 & 0.40 & 0.89 & 0.021 \\
\hline 40,200 & Re-test & 1.39 & 0.38 & 0.90 & 0.022 \\
\hline 40,800 & Methanol Caulyst & 4.12 & 0.91 & 0.97 & 0.021 \\
\hline
\end{tabular}

To coover mikes to $\mathrm{km}$, multiply by 1.609

Clearly the catalyst that had been on the methanol-fueled vehicle showed deteriorated performance in terms of its ability to oxıdize $\mathrm{CO}$ and OMHCE. The catalyst that had been on the gasoline vehicle, after installation on the methanol vehicle, brought the emissions well within the EPA requirements for new vehicles $(3.4 \mathrm{~g} /$ mile $\mathrm{CO} ; 0.41$ $\mathrm{g} /$ mile $\mathrm{HC} ; 1.0 \mathrm{~g} / \mathrm{mile} \mathrm{NO}_{x}$ ). The catalyst swap reduced the aldehyde emissions from around 300 $\mathrm{mg} / \mathrm{mile}(0.3 \mathrm{~g} / \mathrm{mile})$ to $60 \mathrm{mg} / \mathrm{mile}$. For comparison, California has adopted a $15 \mathrm{mg} / \mathrm{mile}$ formaldehyde standard for Low-Emission Vehicles (LEVs), andi an $8 \mathrm{mg} / \mathrm{mile}$ standard for Ultra Low Emission Vehicles (ULEV3) (14). While these aldehyde standards are difficult to achieve, M85fueled vehicles have nonetheless been capable of meeting or surpassing the ULEV standard for aldehydes in student competitions (10-12). The $\mathrm{NO}_{\mathrm{x}}$ reduction efficiency of the catalyst from the methanol Ford did not appear to have seriously deteriorated with use, although this inference can not be made conclusively since raw engine exhaust emissions were not measured (i.e., the methanol engine's raw exhaust may be inherently low in $\mathrm{NO}_{x}$ ).

Buick Regals - The emissions testing on the Buick Regals was not thoroughly extended beyond the initial round of testing, but some preliminary testing was done on one vehicle (9394). This particular vehicle had exhibited rather high emissions during testing conducted immediately following its conversion to M85 fuel use (8). Prior to an anticipated second round of testing (that was precluded by scheduling and budget constraints) the vehicle was subjected to emissions testing that revealed additional deterioration of the emission values. In order to gain some understanding of the results, a new OEM catalytic converter was obtained and further testing was conducted. The results are shown in Table 9. The installation of a new catalyst clearly had a significant effect on the $\mathrm{CO}$ and OMHCE emissions (the catalyst had actually accumulated about $800 \mathrm{~km}$ of service by the time the emission test was conducted).

The old catalyst that was removed from the vehicle had deposits on the inlet side of the monolith that were removed for analysis. The analysis results indicated that the deposits were probably associated with the oil used in this engine. The catalyst was returned to the manufacturer for evaluation where

\begin{tabular}{|c|c|c|c|c|}
\hline \multicolumn{5}{|c|}{ Table 9. Emissions From Buick Regal 9394 } \\
\hline $\begin{array}{c}\text { Odometer } \\
\text { (miles) }\end{array}$ & Condition & \multicolumn{3}{c|}{ FTP emissions (g/mile) } \\
\hline 3.3 & After Conversion & 3.72 & 0.19 & 1.18 \\
\hline 362 & Repeat & 5.13 & 0.23 & 1.18 \\
\hline 401 & Repeat & 6.00 & 0.32 & 1.19 \\
\hline 13,200 & Original Catalyst & 16.1 & 0.69 & 0.63 \\
\hline 15,900 & New Catalyst & 6.29 & 0.25 & 0.77 \\
\hline
\end{tabular}

'To convert miles to $\mathrm{km}$, multiply by 1.609 
tests conducted using gasoline engine exhaust showed no significant deterioration of the catalyst efficiency.

It is speculated that the unburned methanol in the exhaust from methanol-fueled engines might possibly result in the formation of $\mathrm{CO}$ in the catalytic converter as the methanol dissociates into $\mathrm{CO}$ and hydrogen. As the catalyst ages, the relative amounts of $\mathrm{CO}$ formation may increase (as opposed to the complete oxidation of the methanol).

Based on the emissions testing results, it is clear that there may be air quality implications associated with catalyst aging on some M85-fueled vehicles. The data are insufficient to support any conclusions as to what causes the deterioration of catalyst performance but there is some reason to suspect lubricant involvement in the process.

\section{ENGINE OIL ANALYSIS}

\section{Fleet Service}

The engine oil in all FMF vehicles was changed nominally at $4800 \mathrm{~km}$ intervals $(6400 \mathrm{~km}$ at LBL), and sampled at nominal $1600 \mathrm{~km}$ intervals for laboratory analysis of iron, lead, copper, and other wear metal content, as well as for total base number, water content, etc. Normally, linear regressions have been performed on the wear metals data to provide an accumulation rate (the slope of the bestfit line of metal concentration as a function of distance travelled since the last oil change). This was done on a yearly basis and it was noted that iron accumulation rates in the methanol vehicles' oil were greater than those of the gasoline vehicles. Year-toyear however, the iron accumulation rates usually decreased, for both fuel types.

Later in the project, linear regressions were performed on subsets of the data partitioned by calendar quarter or season, and it was noted that seasonal variations did occur, as shown for the ORNL methanol and gasoline Buicks in Figure 1.
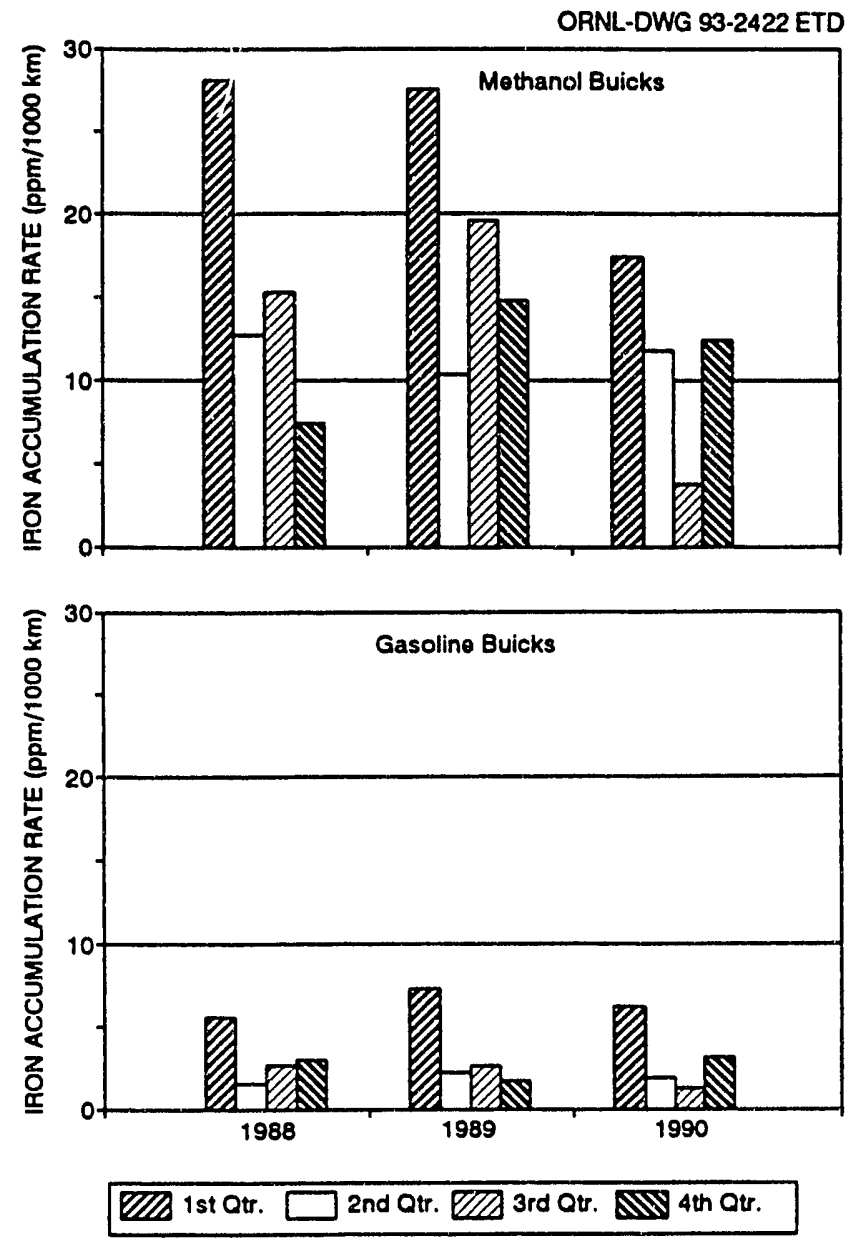

Figure 1. Iron accumulation rate in ORNL Buicks as a function of quarter.

Note that the iron accumulation rates for the methanol vehicles are generally an order of magnitude higher than those for the gasoline vehicles in a given quarter. Note also that the highest accumulation rates occurred in the first (winter) quarter, for both vehicle types. Cold-engine service is known to accelerate engine wear, and hot weather can also accelerate engine wear when combined with high load service (15-17). These facts may partially account for the some of the high iron accumulation rates evident in Figure 1. The results do indicate that there are variations in iron accumulation with changes in ambient temperature.

Figure 2 shows the quarterly iron accumulation rates for the methanol and gasoline Citations at LBL for four years (4). Note again that 


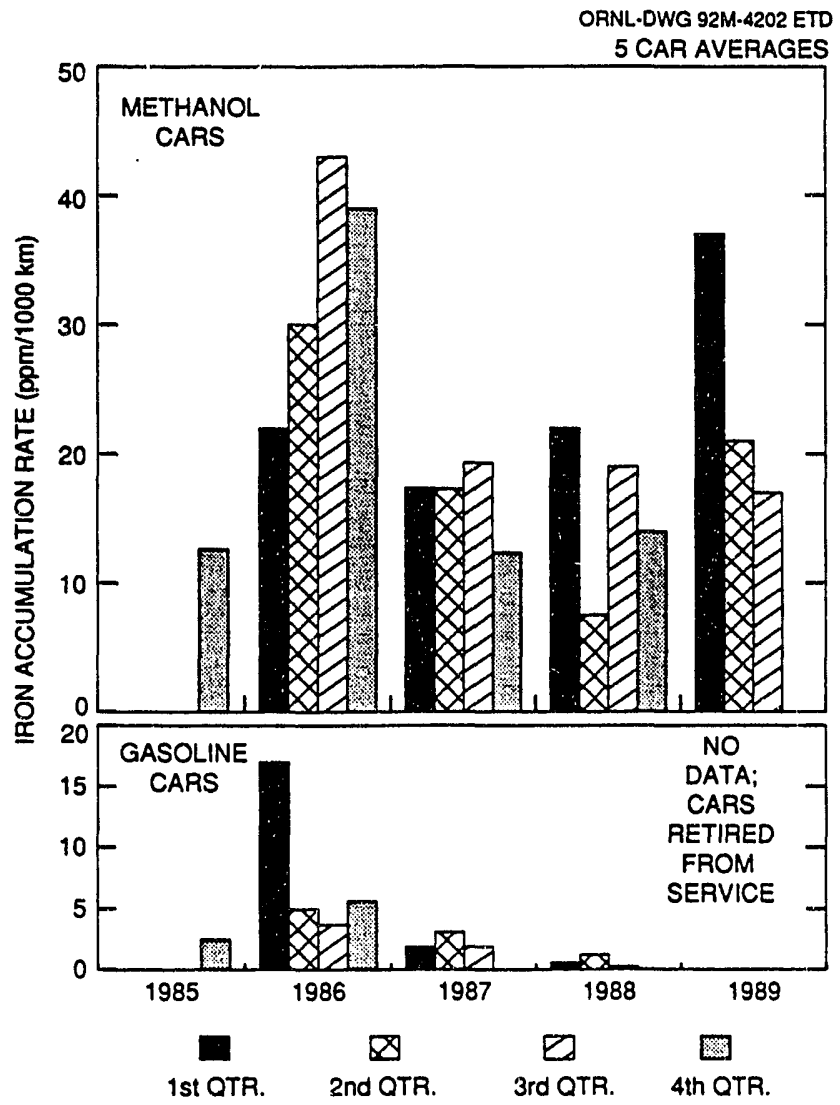

Figure 2. Iron accumulation rate in LBL Chevrolet Citations as a function of quarter.

the accumulation rates in the methanol vehicles are considerably higher than those in the gasoline vehicles. While there is significant variability in the quarterly accumulation rates in the methanol vehicles, the seasonal trends are not as obvious as for the ORNL Buicks, due probably to the milder climate in the Berkeley area. Although there is little variation in ambient temperature at the LBL site, vehicle use patterns from quarter-to-quarter might have differed somewhat, possibly contributing to the variations in iron accumulation noted in the figure. Unfortunately, little data other than trip length were gathered on how the vehicles were driven (e.g., short-trips with repeated cold starts, or high temperature/high load).

The highest iron accumulation rate in the gasoline Citations occurred in the first quarter of 1986. One might attribute this apparent wear to "green engine break-in," however it is important to recognize that the gasoline cars each had over $32,000 \mathrm{~km}(20,000$ miles $)$ on their odometers. The cause of the higher accumulation rate at that time in the vehicle's life is unknown. It is important to note that the iron accumulation rates for the gasoline vehicles prior to being commandeered into the FMF are completely unknown. An interesting observation is that the gasoline car iron accumulation rates generally decline with increasing age.

Figure 3 shows the seasonal iron accumulation rates for the ANL Chevrolets. Because the Chicago area has an extended colder climate, seasons were defined for the ANL site rather than simply using the calendar quarters. The seasons used consisted of a four-month winter, a three-month spring and fall, and a two month summer. The winter season includes two and one-
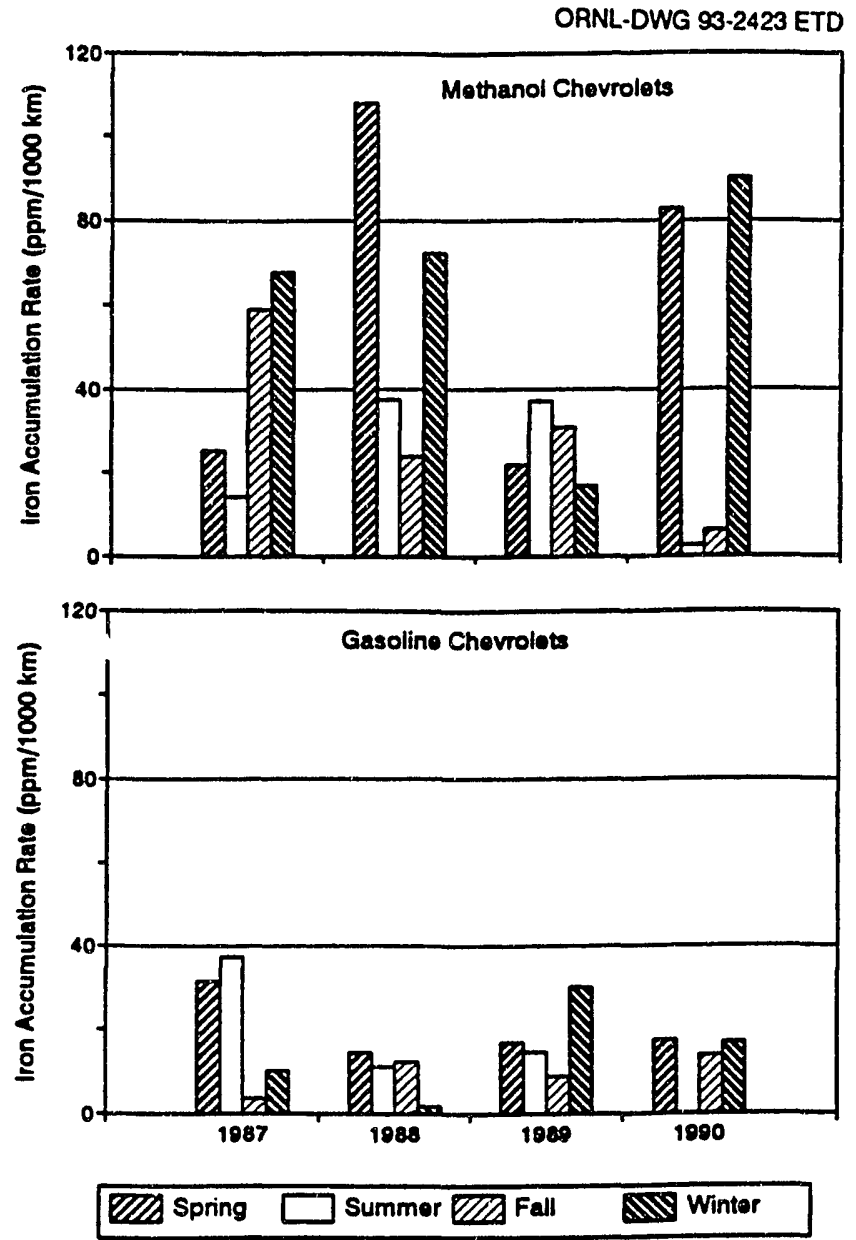

Figure 3. Iron accumulation rate in ANL Chevrolets as a function of seasoñ. 
half months of the subsequent year (i.e., winter 1990 includes January, February, and half of March 1991). Note in the figure that while the methanolvehicle iron accumulation rates are considerably higher than those of the gasoline counterparts, the least difference can be noted for 1989 . While the methanol-Chevrolet iron accumulation rates generally decreased with age (except for a couple of high seasons), the gasoline-vehicle rates remained relatively constant. The majority of the highest rates for both vehicle types are in the spring and winter seasons.

The seasonal iron accumulation rates for the ANL Fords are shown in Figure 4. Except for the peak in the summer of 1989 , the iron accumulation rates for the methanol Fords show a general decrease following the winter of 1987 . The iron
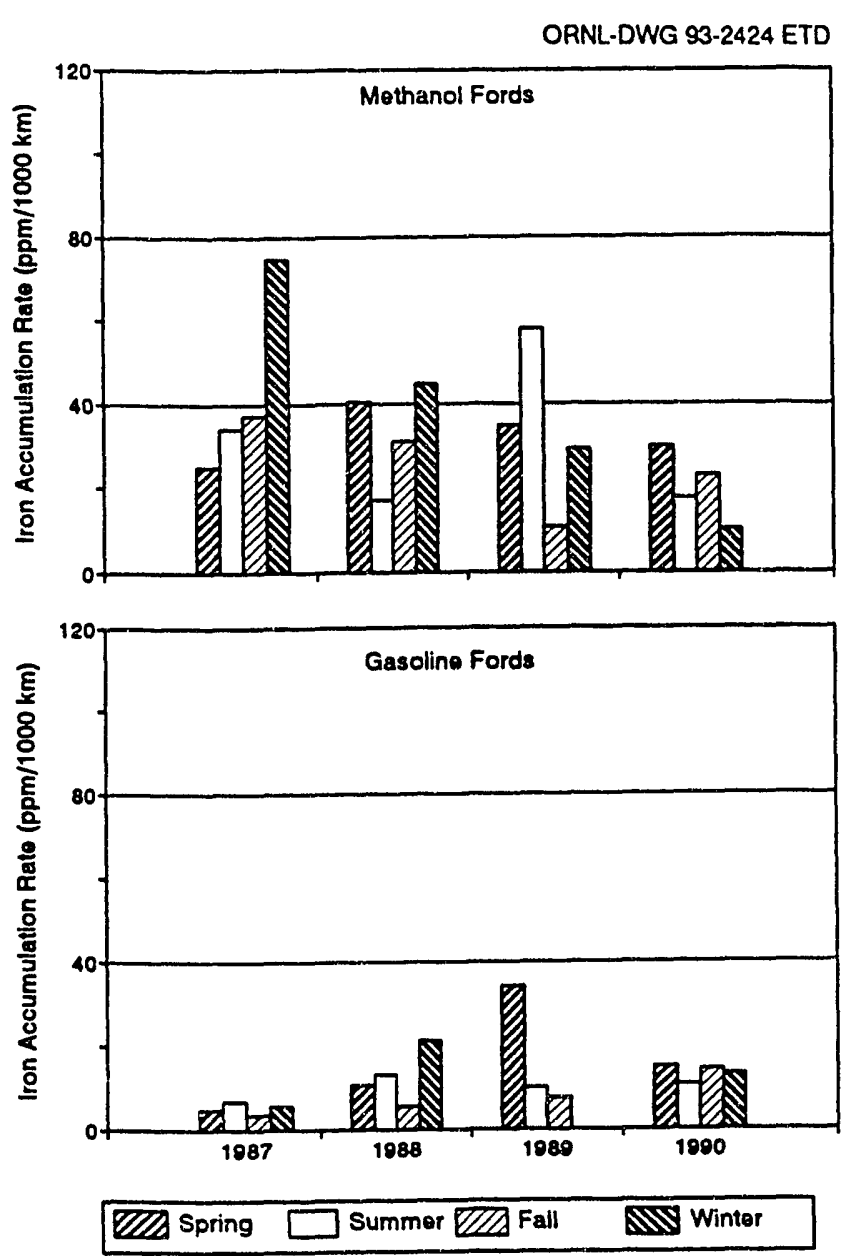

Figure 4. Iron accumulation rate in ANL Fords as a function of season. accumulation in the gasoline Fords, on the other hand, seem to have increased with age up to the spring of 1989, and then leveled off. Reasons for these phenomena are not known.

The data base created in this project shows that, in most cases, the iron accumulation rate is higher in the methanol vehicles. The limited budget of the project did not allow investigatir..o whether or not the higher iron accumulation rates were actually caused by significant increases in engine wear. However, with the interest and assistance of industry, some of the ANL Ford engines were examined in a cooperative effort between DOE, Lubrizol, and Ford. The surplused engines were provided by ANL and DOE, and Lubrizol and Ford cooperated on the disassemblies and inspections. Three of the methanol engines and one gasoline engine were examined.

Although the pistons and rings in the methanol engines were not the same as those in the OEM gasoline vehicle, the findings of the inspections are still of interest. The methanol Ford engines experienced increased piston ring wear apparently caused by calcium deposits in the top ring groove. The average compression ring side clearance for the methanol engines ranged from 0.16 to $0.30 \mathrm{~mm}$, while that of the gasoline engine was $0.13 \mathrm{~mm}$. The oil used in the methanol engines contained relatively high calcium for an automotive oil formulation, although not higher than that used in many diesel formulations $(15,18)$. The gasoline vehicles used a standard, manufacturerrecommended, $10 \mathrm{~W}-30$ engine oil that is routinely stocked by ANL. Calcium deposits were also evident on the methanol-engine piston crowns and valve tulips.

While all four engines showed signs of high cylinder bore wear, the gasoline engine, contrary to expectations, actually had worse wear near top dead center. The M85 engines, on the other hand, showed more evidence of rusting. Surface roughness measurements showed the cylinder bores of all four engines to be similar, although the corroded crankshaft journals of the M85 engines 
were not as smooth as those of the gasoline engine. The gasoline engine had more sludge and varnish deposits than did the methanol-fueled engines (19).

\section{Short-Trip Testing}

From late-winter to mid-summer of 1990 , two of the ORNL Buicks were subjected to severe short-trip service to determine the harmful effects of two types of cold-start, short-trip service on the lubricating oil being used in the methanol vehicles. One methanol and one gasoline vehicle were removed from routine fleet service for the testing.

The first phase of the two-part experiment investigated the effects of severe short-trip driving in which large amounts of methanol and water were allowed to collect in the oil of the methanol vehicle. In the second phase, the trip length was increased to the point that the oil became warm enough to remove (evaporate) the methanol.

The ORNL FMF methanol vehicles' oil was supplied by Lubrizol, Inc. and was formulated as shown in Table 10. This oil is essentially the same

\begin{tabular}{||c|c||}
\hline \multicolumn{2}{|c|}{$\begin{array}{c}\text { Table 10. Oil Formulation Used in } \\
\text { Methanol Vehicles at ORNL }\end{array}$} \\
\hline $\begin{array}{c}\text { SAE Viscosity } \\
\text { Grade }\end{array}$ & \multicolumn{1}{|c||}{$10 \mathrm{~W}-30$} \\
\hline \multirow{4}{*}{ Viscosities } & $10.37 \mathrm{cSt}$ at $100^{\circ} \mathrm{C}$ \\
\cline { 2 - 3 } & $69.5 \mathrm{cSt}$ at $40^{\circ} \mathrm{C}$ \\
\cline { 2 - 3 } & $3450 \mathrm{cP}$ at $-20^{\circ} \mathrm{C}$ \\
\hline TAN & 4.3 (measured) \\
\hline TBN & $\begin{array}{l}8.7 \text { (theoretical) } \\
\text { T.0-9.8 (measured) }\end{array}$ \\
\hline \multirow{2}{*}{ Sulfated Ash } & $1.1 \%$ \\
\hline \multirow{4}{*}{ Elements } & $0.05 \%$ Calcium \\
\cline { 2 - 3 } & $0.15 \%$ Magnesium \\
\cline { 2 - 3 } & $0.20 \%$ Zinc \\
\cline { 2 - 3 } & $0.11 \%$ Phosphorus \\
\hline
\end{tabular}

as the oil referred to as "modified T" by Chamberlin and Gordon (15). While the gasoline vehicles in fleet service used a commercially available motor oil, both of the test vehicles used the Lubrizol oil formulation for the short-trip experiments.

Introduction - As previously noted, a problem area for lubrication of methanol vehicles is short-trip, cold-engine service $(15,17,19-24)$. Under these cold-engine conditions, unburned fuel, condensed water, and other combustion products enter the crankcase by blow-by and become diluted in the relatively cool oil. Under normal driving conditions in which the oil is allowed to warm to temperatures above about $60^{\circ} \mathrm{C}$, many of these contaminants evaporate and are thus removed. The presence of methanol and water in the lubricating oil can remove additives, cause the formation of emulsions, impair lubrication, and increase corrosion. These problems are of special concern for methanol-fueled engines because combustion of M85 produces about $90 \%$ more water than does gasoline combustion (for equivalent energy release). Methanol and water are miscible with each other but form emulsions in engine oil. Gasoline, on the other hand, is miscible with engine oil.

Experiment - In preparation for the experiment, two of the Buicks (one methanol and one gasoline) were outfitted with thermocouples and other instrumentation. The two vehicles were chosen from the fleet of ten based on the criterion of nearly equal odometer mileage. The gasoline Buick began the experiment with $29,240 \mathrm{~km}$ and the methanol Buick with $27,040 \mathrm{~km}$.

Prior to the start of the experiment, each vehicle's oil sump was "double-flushed" (i.e., the oil was changed twice in each vehicle), First each vehicle's oil and filter were changed. Each vehicle was then driven approximately $13 \mathrm{~km}$ and the oil and filter were changed again. Following the second change, the vehicles were driven $0.5 \mathrm{~km}$ and parked until actual testing began.

Type K thermocouples were inserted through the sides of the vehicles' oil pans to measure sump 
temperature, and into the water jackets at the pump outlet to measure coolant temperature. Thermocouples were also mounted on each vehicle's radio antenna to measure the ambient air temperature. The vehicles' stock cam-positionsensor signals were employed to measure engine speed/revolutions. A Campbell Scientific 21X micrologger was used in each vehicle to monitor, process, and record all of the above signals.

Oil Analysis - The oil from each vehicle was sampled and analyzed periodically throughout the experiment. Samples were drawn through the dipstick tubes using a small hand pump and polyethylene tubing. Fresh tubing was used for each sample. The properties measured and the methods used are shown in Table 11. Although the samples were tested for glycol content, glycol results are not presented because the levels were undetectable in all samples.

\begin{tabular}{|c|c|c|}
\hline \multicolumn{2}{|c|}{ Table 11. Methods used in oil analysis } \\
\hline \hline Quantity & Abbreviation & Method \\
\hline Total base number & TBN & ASTM D 2896 \\
\hline Total acid number & TAN & ASTM D 664 \\
\hline Pentane insolubles & PIN & ASTM D 893 \\
\hline $\begin{array}{c}\text { Glycol content } \\
\text { (percent) }\end{array}$ & - & GLYTEC Test Kit \\
\hline $\begin{array}{c}\text { Water dilution } \\
\text { (percent) }\end{array}$ & ASTM D 1744 (Karl \\
\hline $\begin{array}{c}\text { Gasoline dilution } \\
\text { (percent) }\end{array}$ & - & \begin{tabular}{c} 
ASTM D 3525 \\
\hline $\begin{array}{c}\text { Methanol dilution } \\
\text { (percent) }\end{array}$
\end{tabular} \\
\hline $\begin{array}{c}\text { Metals concentration } \\
\text { (parts per million, } \\
\text { ppm) }\end{array}$ & - & $\begin{array}{c}\text { Packed column gas } \\
\text { chromatography }\end{array}$ \\
\hline $\begin{array}{c}\text { Oxidation stability } \\
\text { (minutes) }\end{array}$ & DSC & $\begin{array}{c}\text { Rotating disk optical } \\
\text { emission } \\
\text { calorimetry at } 175^{\circ} \mathrm{C} \\
\text { and 4.14 MPa } \mathrm{O}_{2} \\
\text { pressure }\end{array}$ \\
\hline \hline
\end{tabular}

Procedures - The details of cumulative distance driven and sample intervals for the phases can be found in Figures 5 and 6. Phase 1, shown schematically in Figure 5, consisted of 40 short trips that averaged $1.5 \mathrm{~km}$ in length, followed by a single

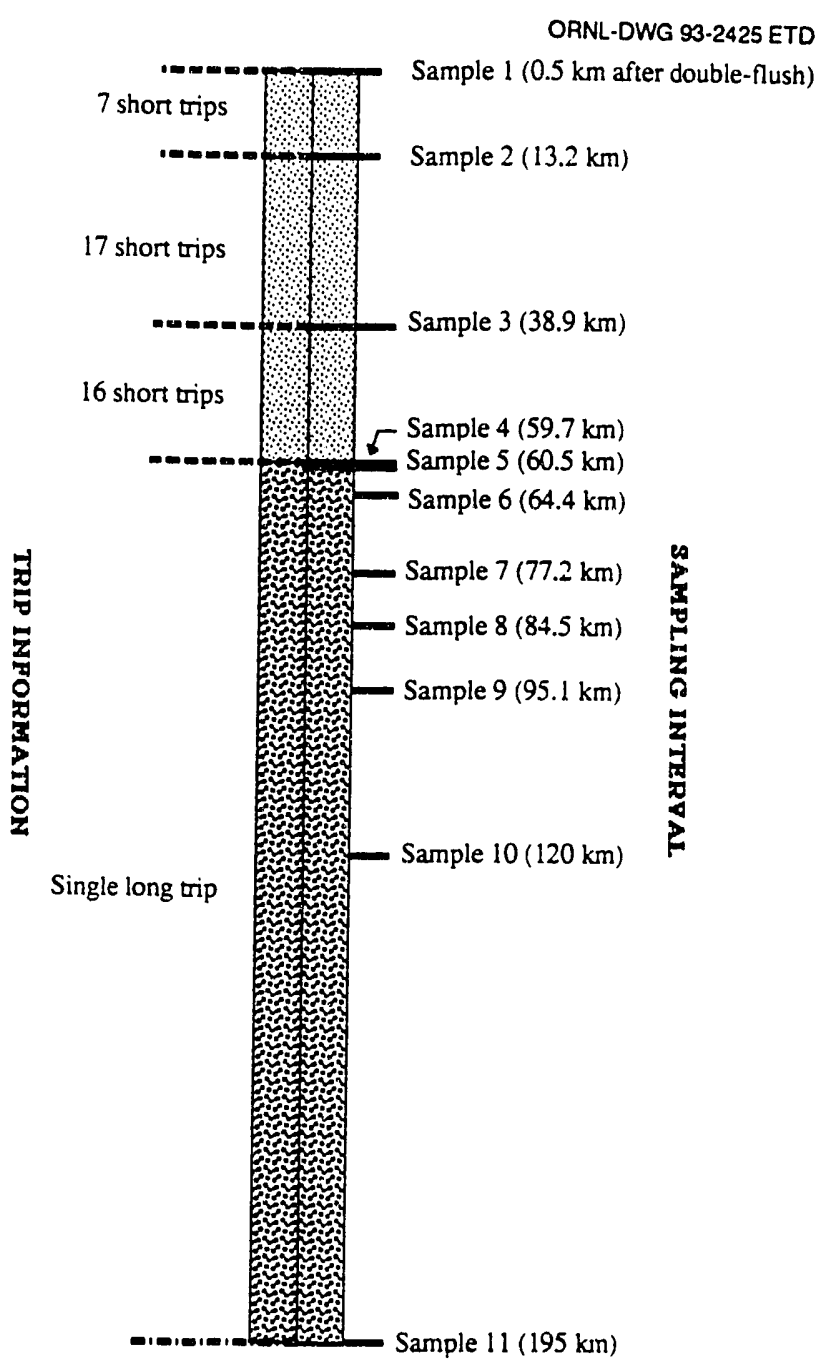

Figure 5. Phase 1 schematic diagram.

$135 \mathrm{~km}$ trip of highway driving. Phase 2 , shown in Figure 6, began with $735 \mathrm{~km}$ of fleet service and highway driving, and was followed by the longer 2.7-km short trips. Phase 2 short-trip testing ended with a $37-\mathrm{km}$ highway trip.

During both phases of the short-trip testing, the vehicles were started at the same instant, driven simultaneously, and shutdown at the same instant. Drivers switched cars every trip in an attempt to equalize any small operator variations. Given that the methanol vehicle was prone to longer cranking times on cool days, the driver of the gasoline vehicle was instructed to wait until the methanol vehicle was starting before initiating cranking. This process helped to ensurc that each vehicle experienced 


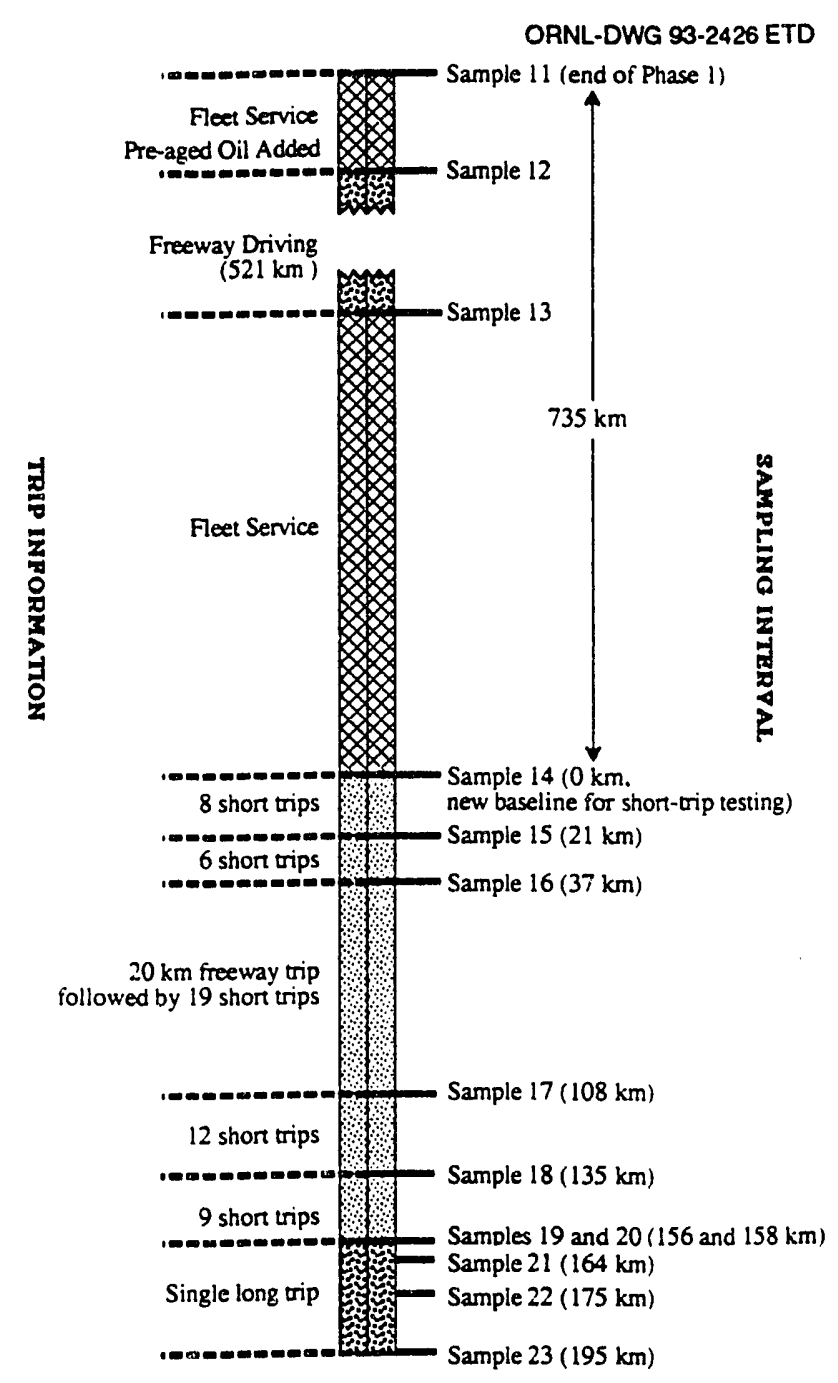

Figure 6. Phase 2 schematic diagram.

approximately the same number of engine cycles throughout the short-trip testing. Unfortunately, an open circuit in the cam-position-sensor signal of the methanol vehicle precluded obtaining the revolutions data during the single long trip of Phase 1 . However, for the period for which revolutions were measured, the total number of revolutions were within $2 \%$ of each other (the methanol vehicle being slightly higher). During the Phase 2 short-trip testing and the subsequent long trip, the methanol vehicle's engine revolutions were about $6 \%$ higher than that of the gasoline engine. The reason for the higher number of engine cycles was probably related to the methanol vehicle's engine control module
(ECM) which was reprogrammed for slightly higher idle speed under cold engine conditions. This was not considered to be an important factor, however, because the transmissions were in gear and the vehicles were being driven at the same speed during cold engine operation.

Phase 1 - The initial plan for Phase 1 was to complete two 2-km trips per day until 40 trips had been completed. However, unseasonably warm temperatures called for shorter trips and precluded making a second trip on most days. Nonetheless, forty trips were completed, totaling only $60 \mathrm{~km}$.

Because the objectives of the experiment were to determine the deleterious effects of volatile contaminants in the engine oil and the effects of oil temperature on the level of contaminants and rates of degradation, it was decided that one shorter trip per day would be more prudent than two 2-km trips, in order to avoid boiling off appreciable amounts of volatile contaminants. While colder ambient temperatures and longer trips would have been preferred, the extremely short trips were the best means available to ensure that the vehicles' oil temperatures remained low.

Pre-aged Makeup Oil - Following the Phase 1 long trip (during which several oil samples were taken) and before the beginning of the Phase 2 testing, a similar volume (about 1.1 liters) of preaged make-up oil was added to each vehicle. The pre-aged oil was obtained from another methanol Buick that had accumulated about $2700 \mathrm{~km}$ on its oil in typical fleet service. The oil was taken from one of the methanol Buicks because these were the only cars available that were using the oil formulation being tested (the other gasoline FMF cars used commercially available oil).

Pre-aged make-up oil was added in lieu of fresh oil to minimize any significant improvement in the oils' protective properties. Ideally, oils used for this purpose would be pre-aged in similar vehicles driven under similar service conditions for the same distances (25). However, no such oil was available. The test vehicles had each accumulated $195 \mathrm{~km}$ at 
the time the make-up oil was added. Based on the literature, it was reasonable to assume that the shorttrip service would be 10-15 times more detrimental to the oil than combined highway/city driving for the same distance. Therefore, the oil with $2700 \mathrm{~km}$ of fleet service was considered appropriate.

The analysis results for the pre-aged makeup oil are shown in Table 12. Also shown are the analysis results for the fresh oil and the samples drawn from each of the test vehicles prior to and following the pre-aged oil addition. Note that the oxidation stability (DSC) of the pre-aged oil is only 4 minutes. Although considerably lower than expected, the exact type of service to which this vehicle had been subjected was unknown. It is clear that the addition of pre-aged make-up oil did not improve the condition of the oil in the vehicles' sumps. In fact, the results in Table 12 indicate that the used-oil addition actually resulted in degradation of the resultant sump contents.

\begin{tabular}{|c|c|c|c|c|c|c|c|c|}
\hline \multicolumn{9}{|c|}{$\begin{array}{l}\text { Table } 12 \text { Analysis results for fresh, pre-aged, and test vehicle oil samples } \\
\text { before and after oil addition }\end{array}$} \\
\hline Sample & TAN & TBN & PIN & $\begin{array}{l}\text { gasoline } \\
\text { dil'n }(\%)\end{array}$ & $\begin{array}{l}\text { methanol } \\
\text { dil'n }(\%)\end{array}$ & $\begin{array}{l}\text { water } \\
\text { dil'n } \\
(\%)\end{array}$ & $\begin{array}{l}\text { iron } \\
\text { conc. } \\
\text { (ppm) }\end{array}$ & $\begin{array}{l}\text { DSC } \\
(\min )\end{array}$ \\
\hline $\begin{array}{c}\text { Fresh oil (2 } \\
\text { sample } \\
\text { average) }\end{array}$ & 4.3 & 9.4 & 0.0 & 0 & 0 & 0.07 & 0 & 96 \\
\hline $\begin{array}{c}\text { Pre-aged oil } \\
\text { (2 sample } \\
\text { average) }\end{array}$ & 8.7 & 3.7 & 0.6 & 1 & $<1$ & 0.12 & 100 & 4 \\
\hline
\end{tabular}

\begin{tabular}{|c|c|c|c|c|c|c|c|c|}
\hline & & & & Methanol & Vehicle & & & \\
\hline $\begin{array}{l}\text { Before oil } \\
\text { add } \\
\text { (sample 11) }\end{array}$ & 4.1 & 11.7 & $<0.1$ & $<1$ & $<1$ & 0.08 & 60 & 55 \\
\hline $\begin{array}{l}\text { After oil add } \\
\text { (sample 12) }\end{array}$ & 7.5 & 8.5 & $<0.1$ & $<1$ & $<1$ & 0.17 & 60 & 45 \\
\hline $\begin{array}{c}\text { After } \\
\text { highway } \\
\text { (sample 13) }\end{array}$ & 8.3 & 9.5 & $<0.1$ & 2 & $<1$ & 0.21 & 70 & 26 \\
\hline
\end{tabular}

\begin{tabular}{|c|c|c|c|c|c|c|c|c|}
\hline & & & & Gasoline & Vehicle & & & \\
\hline $\begin{array}{c}\text { Before oil } \\
\text { add } \\
\text { (sample 11) }\end{array}$ & 3.3 & 11.0 & $<0.1$ & 4 & 0 & 0.07 & 30 & 47 \\
\hline $\begin{array}{l}\text { After oil add } \\
\text { (sample 12) }\end{array}$ & 7.7 & 8.5 & $<0.1$ & 2 & 0 & 0.15 & 50 & 33 \\
\hline $\begin{array}{c}\text { After } \\
\text { highway } \\
\text { (sample 13) }\end{array}$ & 7.2 & 9.2 & $<0.1$ & 2 & 0 & 0.16 & 60 & 25 \\
\hline
\end{tabular}


Phase 2 - Following the addition of make-up oil, both vehicles were driven $702 \mathrm{~km}$ before beginning the longer short-trip service. Again, the types of service are depicted in Figure 6. Table 12 shows the analysis results for samples taken after the $521 \mathrm{~km}$ of highway driving. On inspection of the oxidation stabilities, it is apparent that the oils were further degraded by the highway driving, although their total base numbers improved slightly. The vehicles were not driven "side-by-side" during portions of this period of fleet and highway service. They did, however, see nearly identical service and accumulated identical mileage.

The Phase 2 short-trip testing, like that of Phase 1 , was initially designed to be comprised of 40 short trips. However, an unavoidable trip to the garage after 14 short trips interrupted the experiment. This interruption is indicated in Figure 6 as the $20-\mathrm{km}$ trip after Sample 16. Following this intermittent long trip, 40 more short trips were made.

Discussion of Phase 1 - In Phase 1 of the experiment, the trips were sufficiently short that the sump temperatures did not exceed $60^{\circ} \mathrm{C}$ except in the long trip at the end. Surprisingly, the methanol vehicle's oil temperature was consistently higher than that of the gasoline vehicle even though the coolant temperature was actually lower, as shown for a typical short-trip in Figure 7. Lower coolant temperatures would be expected in the methanol vehicle due to methanol's slightly lower flame temperature and much higher latent heat of vaporization. By the same reasoning, lower oil temperatures would be expected. One possible explanation for the higher oil temperatures is that there may have been a higher level of hot blow-by gases in the crankcase of the methanol vehicle caused by increased cylinder bore and ring wear.

The Phase 1 oil and ambient temperatures are shown in Figure 8. The oil data up to $60 \mathrm{~km}$ are the peak temperatures reached during the daily short trips. From $60 \mathrm{~km}$ to $195 \mathrm{~km}$ (single long trip), the oil temperatures are those recorded each

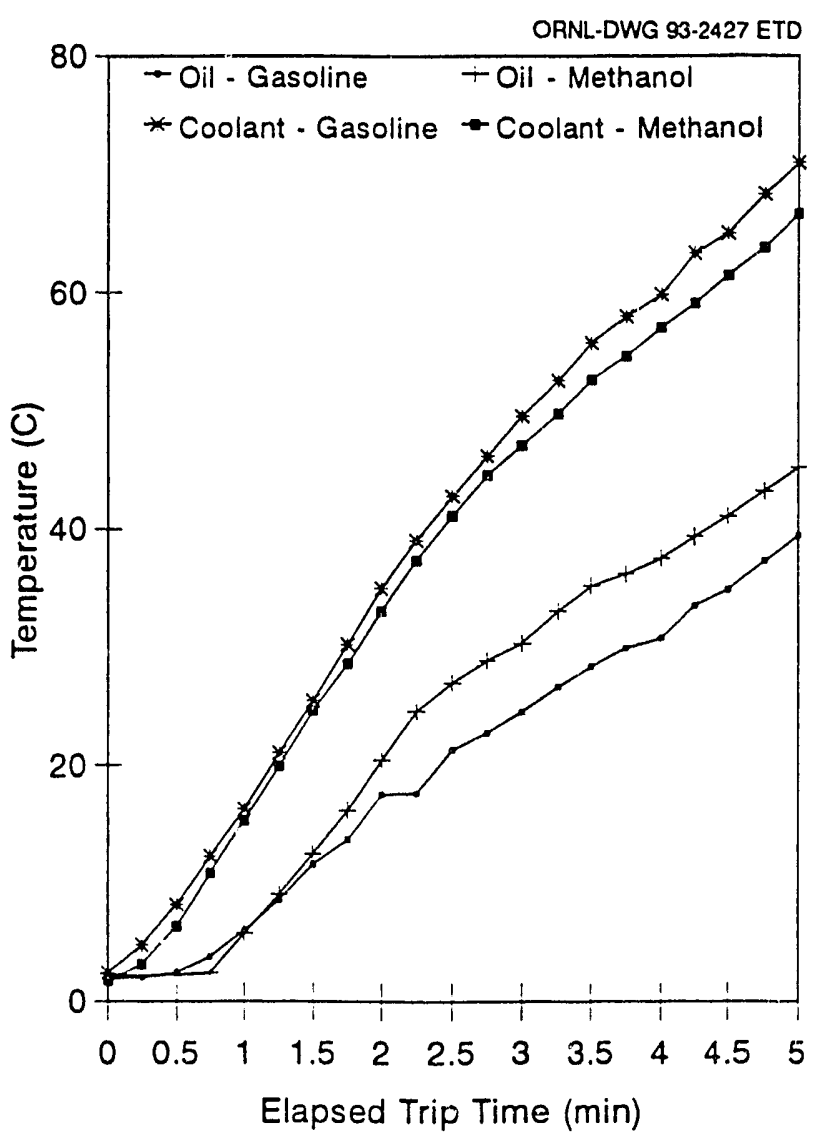

Figure 7. Methanol and gasoline vehicle oil and coolant temperatures for a typical shorttrip.

time a sample was taken. Again, the higher methanol vehicle oil temperatures are quite apparent.

Warmer oil temperatures notwithstanding, the methanol vehicle's oil still accumulated a larger volume of volatile contamination. Figure 9 shows the total volatile contamination (sum of water, gasoline, and methanol dilution) in the oil of each vehicle. Note that the peak volatile content of the methanol vehicle is more than double that of the gasoline vehicle.

Figure 10 shows the fuel and water contamination separately for the methanol vehicle, and Figure 11 shows the same information for the gasoline vehicle. The gasoline vehicle's fuel dilution peaked at about $12 \%$ with only a few percent of water dilution. The fuel contamination only dropped to $5 \%$ after the $135 \mathrm{~km}$ of freeway driving at elevated temperatures. 


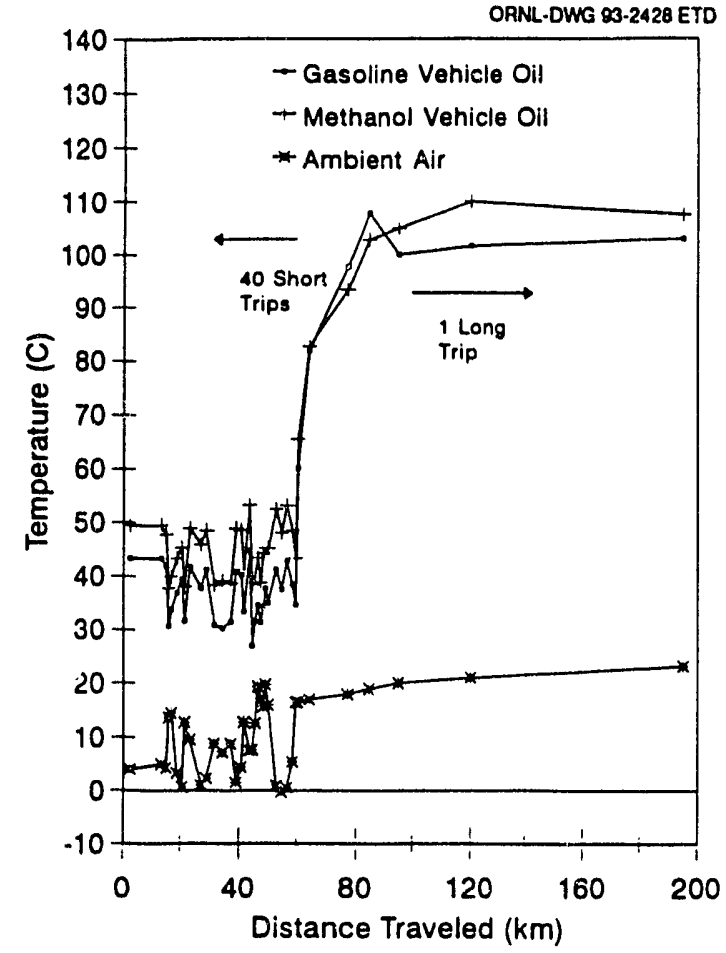

Figure 8. Phase 1 ambient and oil temperatures for both vehicles.

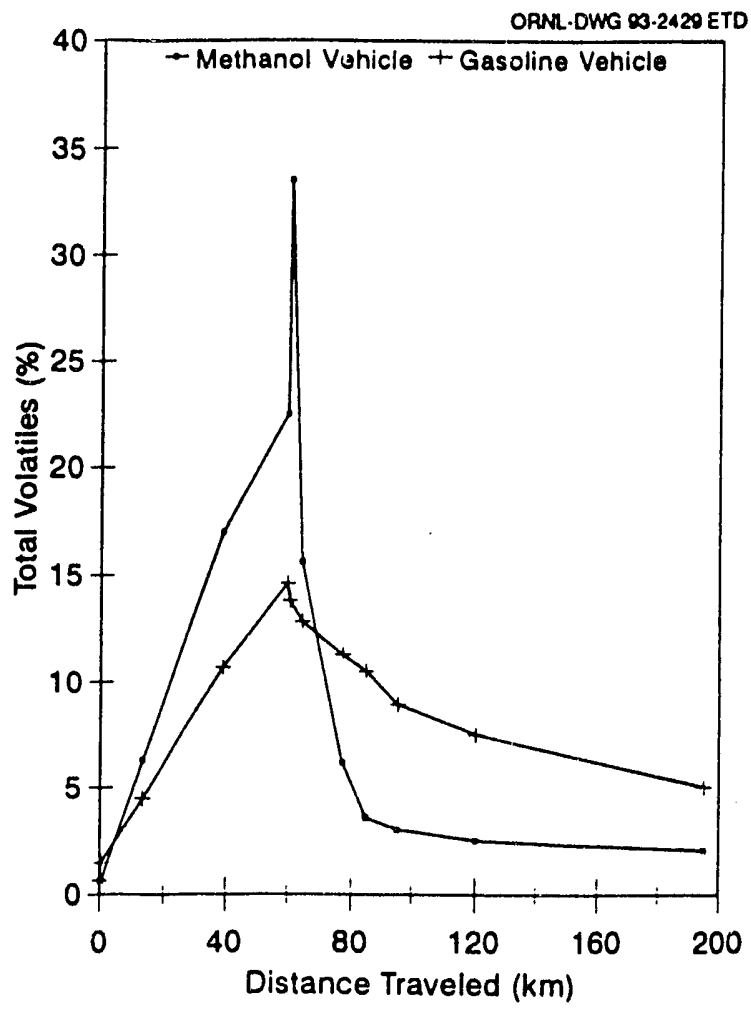

Figure 9. Phase 1 total volatile contamination in oil for both vehicles.

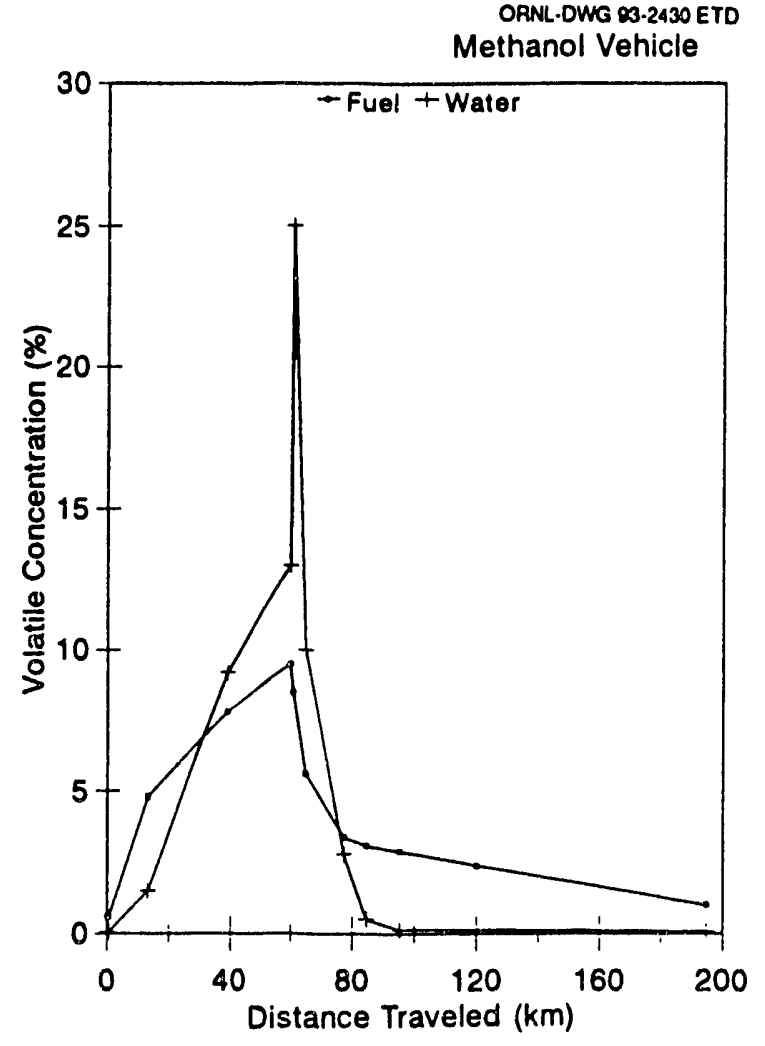

Figure 10. Phase 1 fuel and water dilution in methanol vehicle's oil.

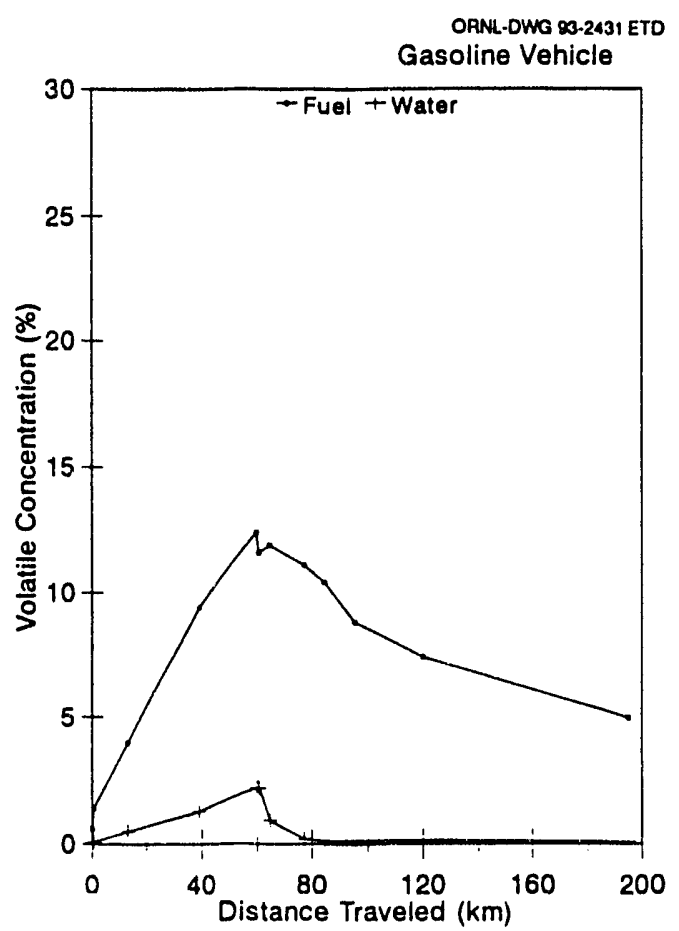

Figure 11. Phase 1 fuel and water dilution in gasoline vehicle's oil. 
The oil readily forms an emulsion with high levels of water and/or methanol, as shown in Figure 12. The first four samples were taken during the 40 short trips. Note that at Sample 3 the specimens look similar, but that at Sample 4 the methanol vehicle's oil is much more emulsified. The long trip included a one-hour "hot-soak," and totaled over four hours in duration. The methanol vehicle's oil had much higher water dilution than did the gasoline vehicle's oil, although the fuel dilution (methanol and gasoline combined) peaked at a slightly lower level. While the water boiled off rather quickly in both vehicles, the fuel contamination in the gasoline vehicle's oil was removed at a much slower rate due to its wide boiling range (typically $25-215^{\circ} \mathrm{C}$ ). Vaporization of fuel in the methanol vehicle's oil occurred quickly at first, due to the single boiling point of methanol $\left(65^{\circ} \mathrm{C}\right)$, but the gasoline portion of the fuel was removed at a slower rate.

The change in TBN is shown in Figure 13. The TBN decreases substantially in both vehicles during the short-trip testing and rebounds during the long trip. The high TBN value shown for the methanol vehicle at about $100 \mathrm{~km}$ is not understood, although the sample was noted to have been "gummy." The contents of this sample were apparently quite alkaline; however, it is most unlikely that the vehicle's entire sump had such a TBN at that time. Results for total acid number are not shown because there was very little variation throughout Phase 1.

The TBN values at the beginning of the short trip testing are quite different. The gasoline vehicle's TBN was much higher than that of the

ORNL-Photo $8254-90$

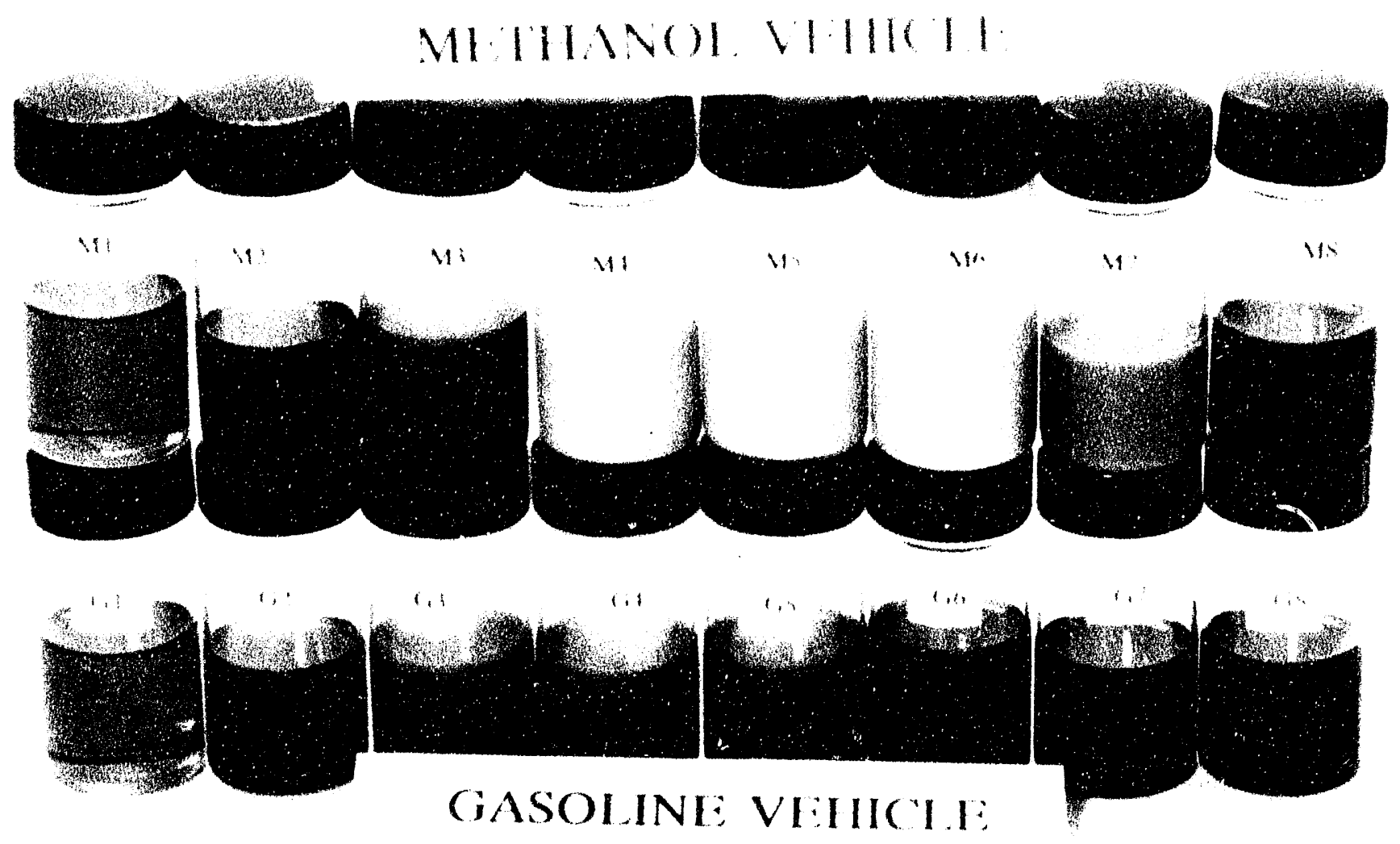

Figure 12. Phase 1 oil samples. 


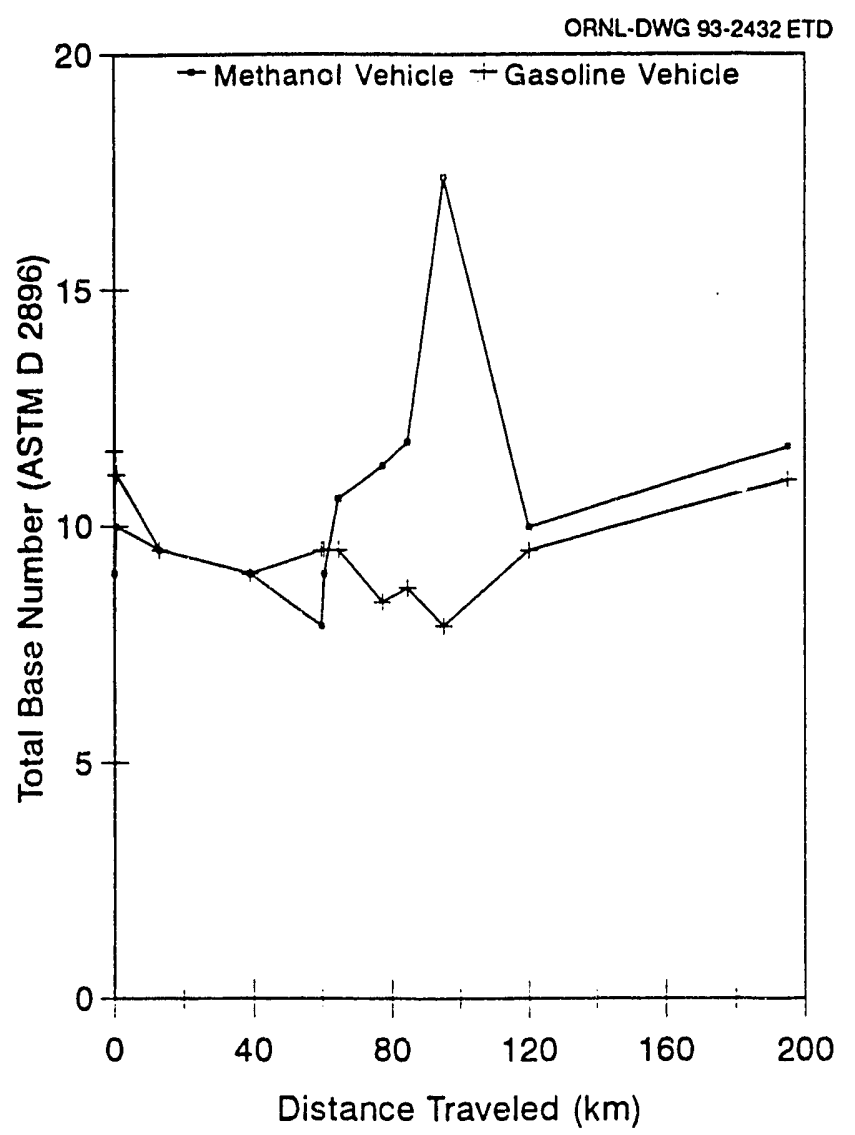

Figure 13. Phase 1 total base number for both vehicles.

methanol vehicle. Reasons for this are not clear. It may be possible that, despite the double-flush oilchange, some residue from the bottom of the oil pans could have contaminated the samples. Unfortunately, the oil drains were not sampled prior to the double-flush.

Figure 14 shows the iron concentrations measured in each vehicle's oil throughout Phase 1. The curve fits shown are quadratic regressions. A quadratic method was used because the iron accumulation rates appeared to level off during the long trip. Figure 14 shows that the iron accumulation rate for the methanol vehicle was higher than that for the gasoline vehicle. Although both curves appear to level off at about the same distance, the methanol vehicle's final iron level was about $20 \mathrm{ppm}$ higher than that of the gasoline vehicle.

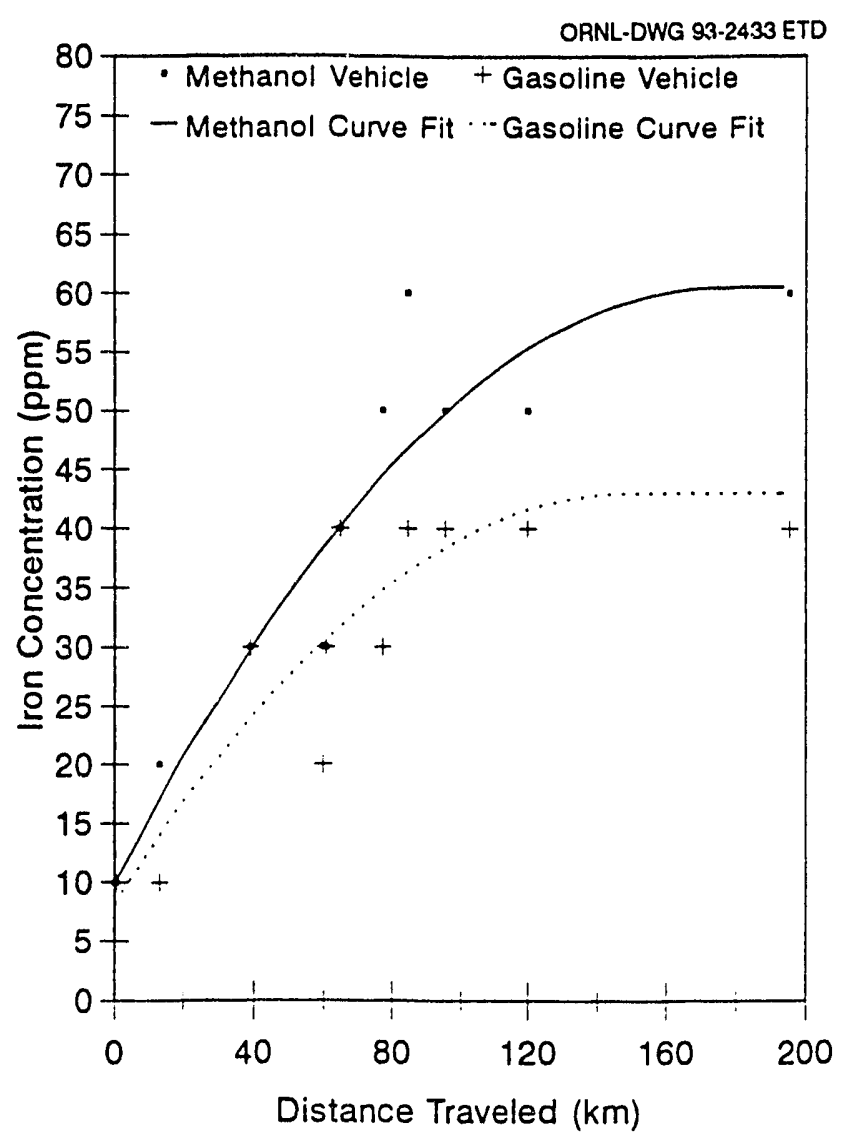

Figure 14. Phase 1 iron concentrations in both vehicles' oil.

Linear regressions were also performed, using only the first 8 values of the Phase 1 data. During the short trip testing, and early in the long trip, the iron accumulation rate for the gasoline vehicle was $335 \mathrm{ppm} / 1000 \mathrm{~km}$ which is over 30 times higher than the highest seen in any winter quarter (Figure 1). The methanol vehicle's oil accumulated iron at a rate of $490 \mathrm{ppm} / 1000 \mathrm{~km}$ which is about 17 times higher than the highest iron accumulation rate shown in Figure 1.

Discussion of Phase 2 - When the short-trip testing portion of Phase 2 began, each vehicle had accumulated $930 \mathrm{~km}$ since the double-flush oil change at the beginning of Phase 1. Sample 14 was drawn to obtain a new baseline and short-trip testing was resumed with longer $2.7-\mathrm{km}$ trips. The average ambient temperature was warmer during this period. 
Figure 15 shows the oil and ambient air temperatures as functions of distance for the last segment of Phase 2. Figure 16 shows the total volatile contamination for both vehicles. During this period, there was no accumulation of methanol, so the sum of fuel and water includes only water and gasoline. The inadvertent long trip after the first 14 short trips is apparent by the increased level of the oil temperatures at about $40 \mathrm{~km}$. During the longer (2.7- $\mathrm{km}$ ) short-trip testing, the methanol vehicle's oil was again warmer than that of the gasoline vehicle, but by a smaller margin. The sump temperatures during this phase were still relatively low, rarely exceeding $70^{\circ} \mathrm{C}$. Note that the peak volatile contamination for the gasoline vehicle is about double that for the methanol vehicle for this warmer short-trip service. The long trip began at $158 \mathrm{~km}$ and ended at $195 \mathrm{~km}$.

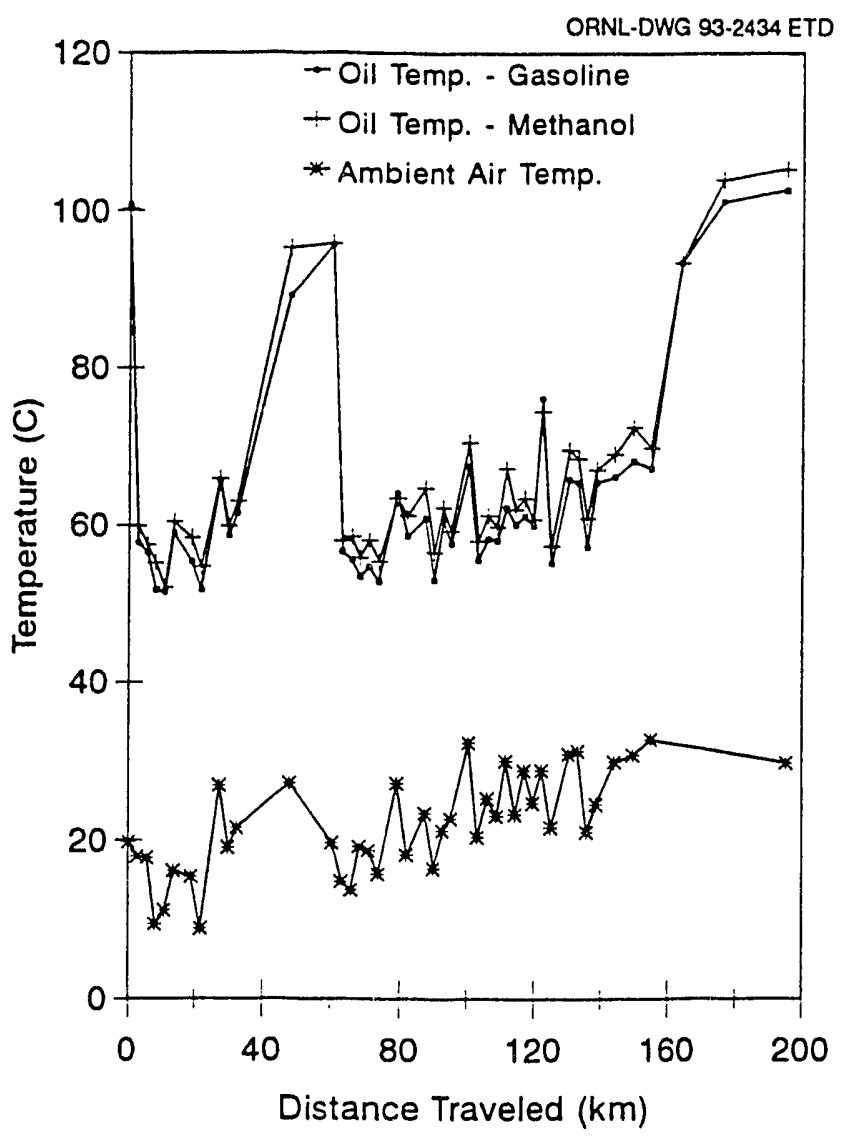

Figure 15. Phase 2 ambient and oil temperatures for both vehicles.

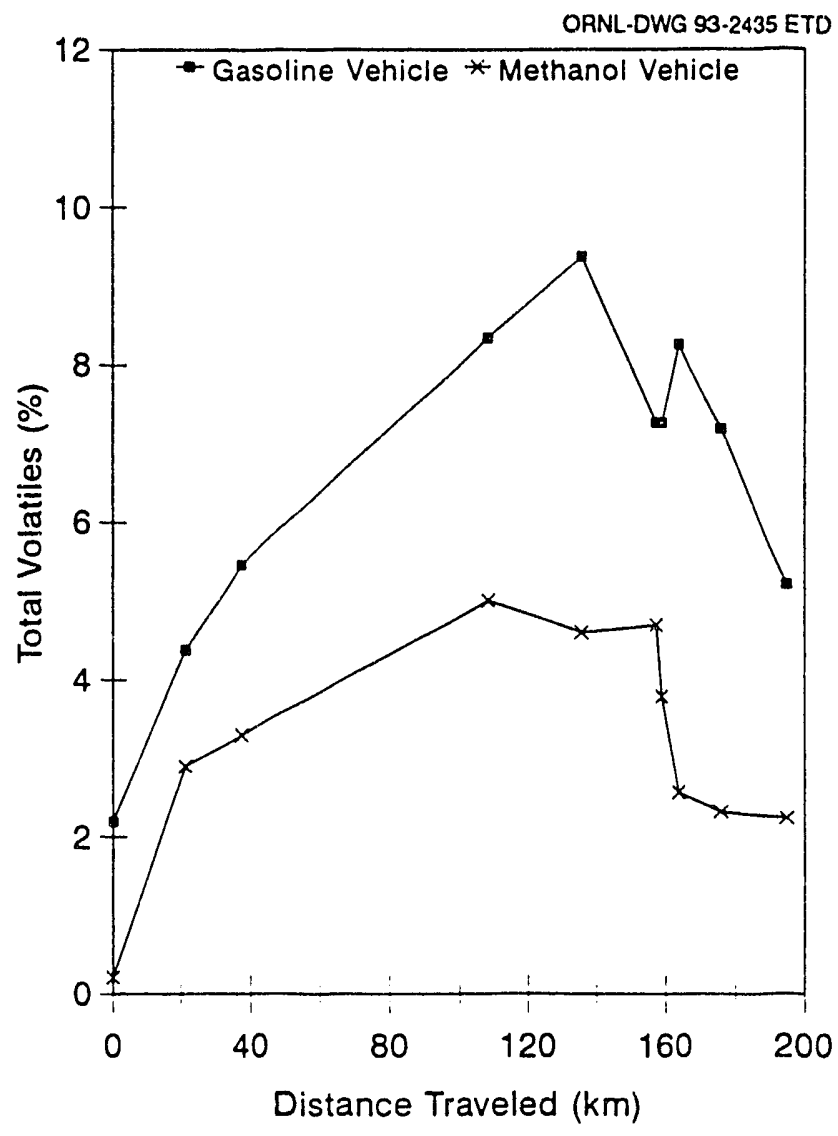

Figure 16. Phase 2 total volatile contamination in oil for both vehicles.

Figure 17 shows the water and fuel dilution for the methanol vehicle and Figure 18 shows the same information for the gasoline vehicle. The warmer sump temperatures precluded any methanol dilution during this phase, however the methanol vehicle's oil still accumulated $2 \%$ gasoline. There was very little water dilution in the gasoline vehicle's oil. During the long trip, the volatiles in the methanol vehicle's oil (being mostly water) were removed at a much higher rate at first. In fact, the gasoline concentration in the methanol vehicle's oil was still $2 \%$ at the end of the long trip. The vehicles were obviously not driven far enough to remove all of the volatile contamination. Given the warmer sump temperatures and the appearance of the oil (samples were not analyzed until all work was completed), it was thought that $37 \mathrm{~km}$ would be a sufficiently long trip. 


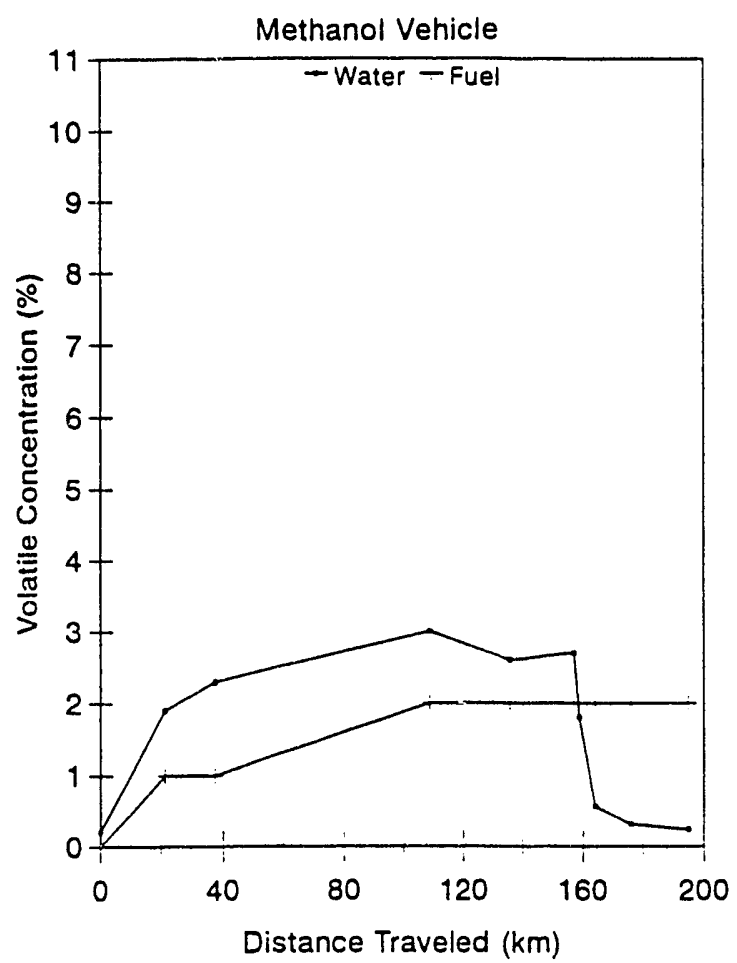

Figure 17. Phase 2 fuel and water dilution in methanol vehicle's oil.

ORNL-DWG 93-2437 ETD

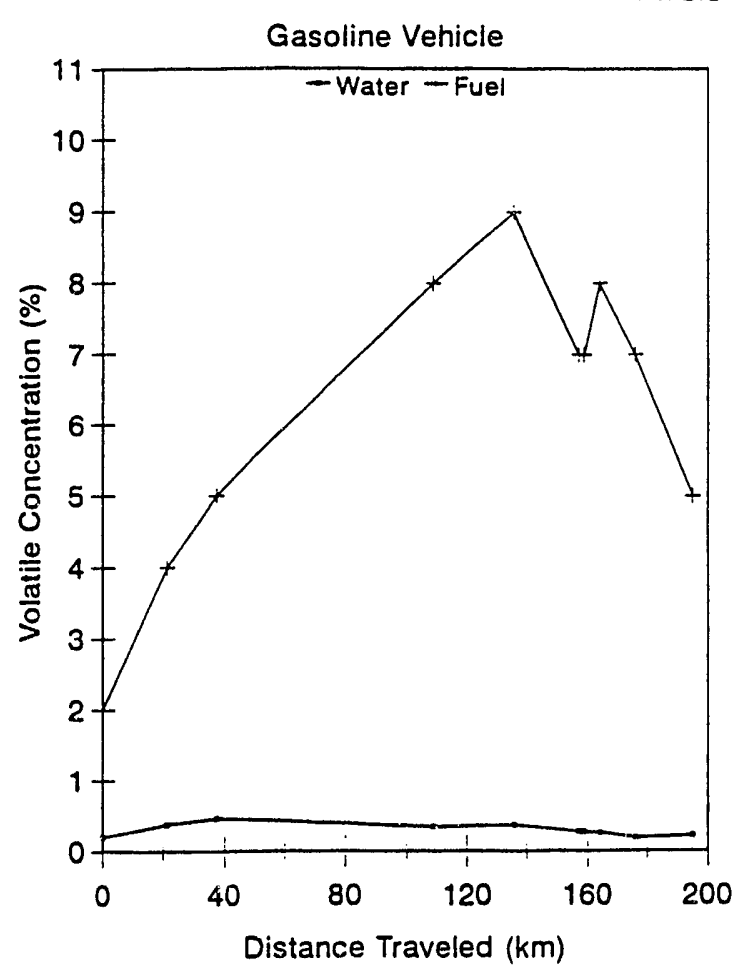

Figure 18. Phase 2 fuel and water dilution in gasoline vehicle's oil.

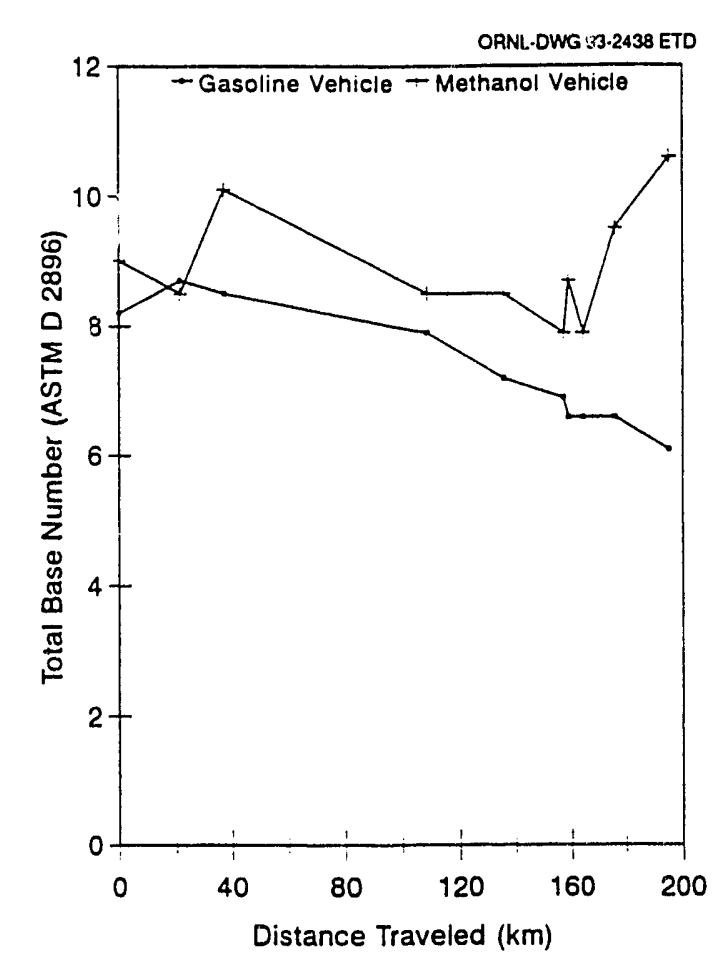

Figure 19. Phase 2 total base number for both
vehicles.

Figure 19. Phase 2 total base number for both
vehicles. steady decrease in the TBN of the gasoline vehicle's oil for this period. The methanol vehicle's TBN followed a similar trend, but increased rapidly to its end-of-Phase-1 value during the long trip.

The iron levels for both vehicles were nearly constant throughout the short-trip portion of Phase 2, as shown in Figure 20. Linear regressions of the data produced a negative iron accumulation rate for the gasoline vehicle, which merely reflects the uncertainty $( \pm 5 \mathrm{ppm})$ in the measureinents. The methanol vehicle's regression shows an increasing trend, largely because of the last two data points. The iron accumulation rate for the methanol vehicle, calculated as described above, was $74 \mathrm{ppm} / 1000 \mathrm{~km}$. Although considerably lower than the $490 \mathrm{ppm} / 1000$ $\mathrm{km}$ found in Phase 1, $74 \mathrm{ppm} / 1000 \mathrm{~km}$ is still more than double any rate shown in Figure 1 (from three years of fleet service). These and other results are presented in more detail in Reference 26. 


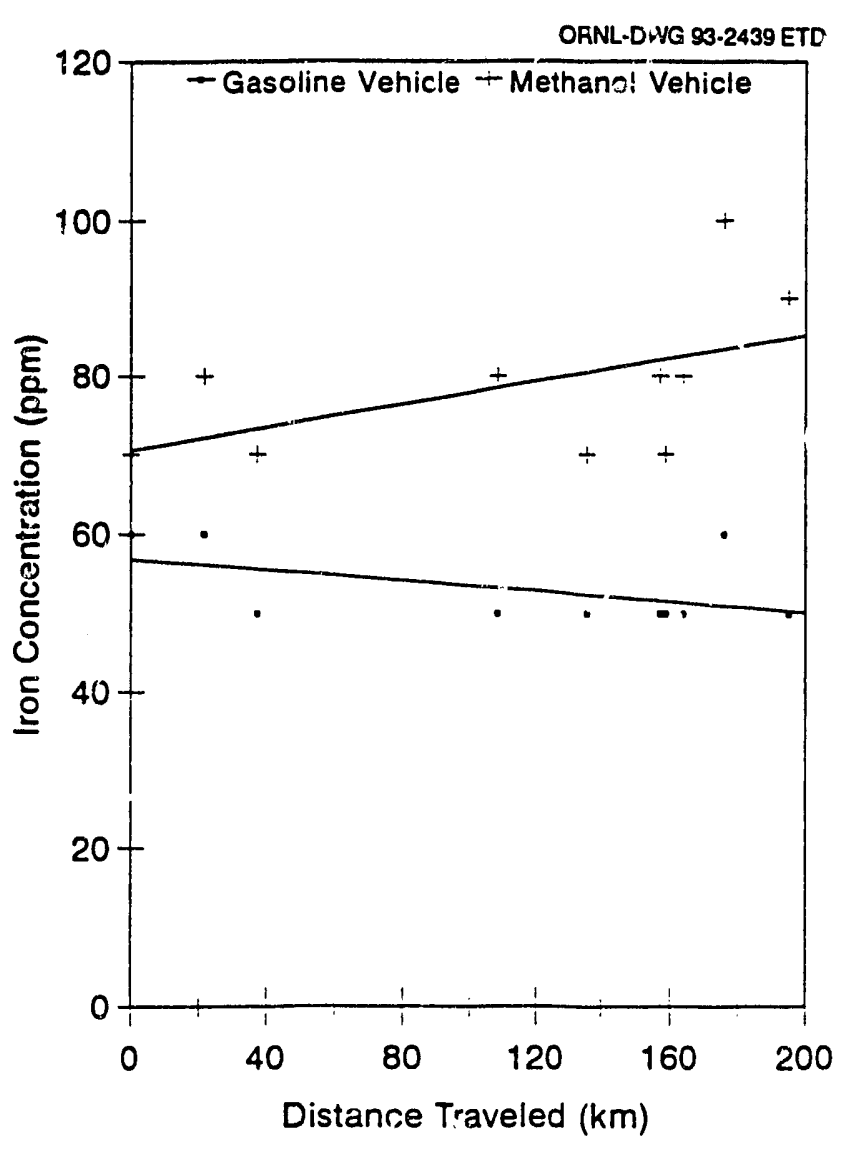

Figure 20. Phase 2 iron concentrations in both vehicles' oil.

\section{COMEARISON OF MAINTENAFICE AND SERVICE}

The data collected over the course of this project showed that the methanol vehicles generally required more overall maintenance than their gasoline counterparts, something one might expect for development or prototype vehicles. The mairtenance data were examined to determine what percentage of the maintenance was "fuel-related" (i.e., corrective or preventative maintenance which could be traced to the fuel or fuel system). Although the methanol vehicles did have higher fuelrelated maintenance than did the gasoline cars, the fuel-related incidents did not always account for the greater amount of overall maintenance. In other words, the methanol vehicles were sent to the shop more frequently, but not due to fuel-related problems. The authors believe that the drivers were more sensitive to mechanical problems in the "special" methanol vehicles and requested maintenance for them on occasions that might have been dismissed for a gasoline vehicle.

For illustrative purposes, Figure 21 shows the maintenance frequency (maintenance events per $1000 \mathrm{~km}$ ) and intensity (labor hours per $1000 \mathrm{~km}$ ) for the Chevrolet S10 pickup trucks at ANL for the first three years of operation. The figure shows that, although the maintenance frequency for the methanol vehicles rose slightly each year, it stayed relatively constant for the gasoline vehicles. The methanol vehicles' maintenance intensity increased markedly each year while that of the gasoline vehicles increased only slightly.
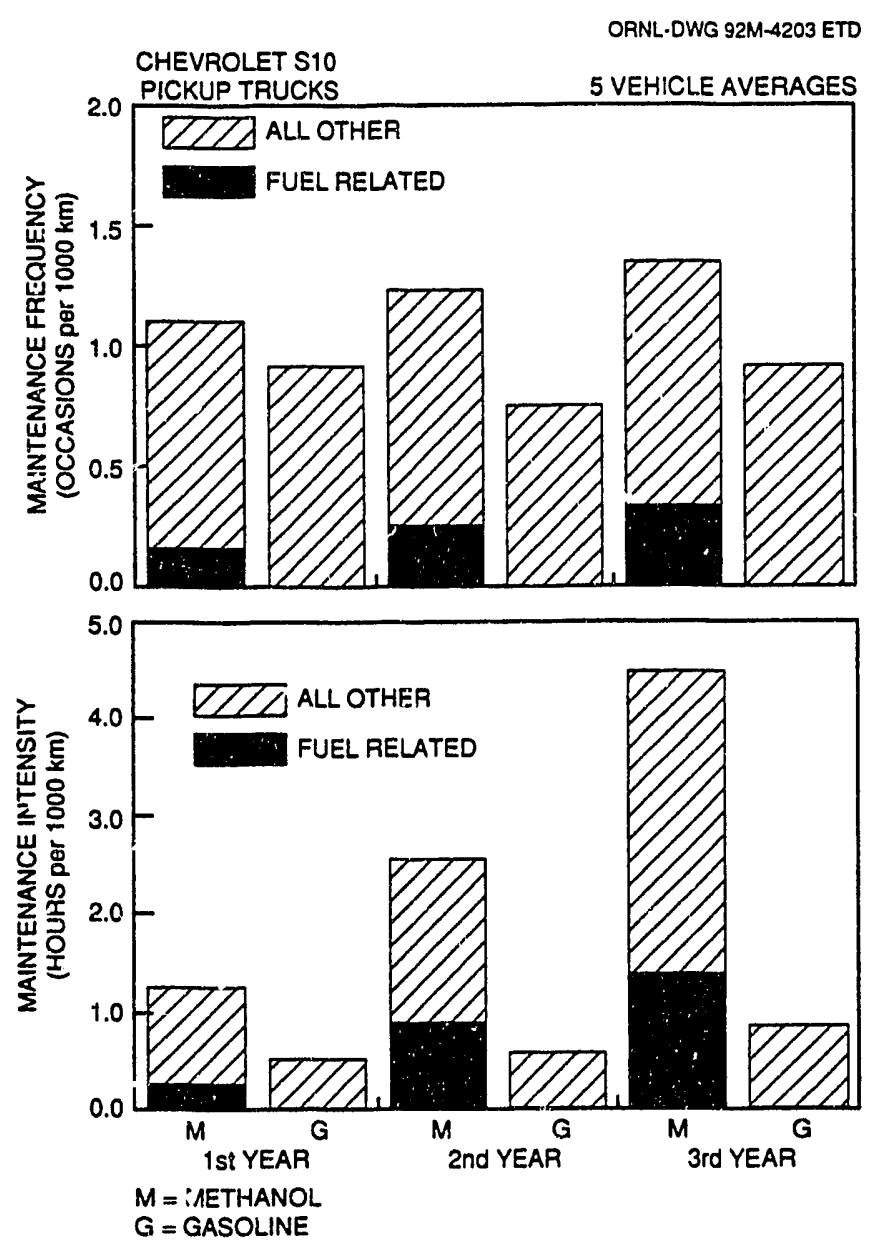

Figure 21. Maintenance frequency and intensity for ANL Chevrolets. 
Similar information is presented in Figure 22 for the Fords at ANL. The maintenance frequency for the methanol Fords increased slightly each year while that for the gasoline Fords was relatively constant. The maintenance intensity increased each year for both fuel types, although at a higher rate for the methanol Fords. Once again, note that the fuelrelated maintenance does not account for the greater overall maintenance of the methanol Chevrolets or Fords, although the "all other" categories for the methanol and gasoline Fords are more equitable.

ORNL.DWG 92M-4204 ETO 5 METHANOL VEHICLE AVERAGES
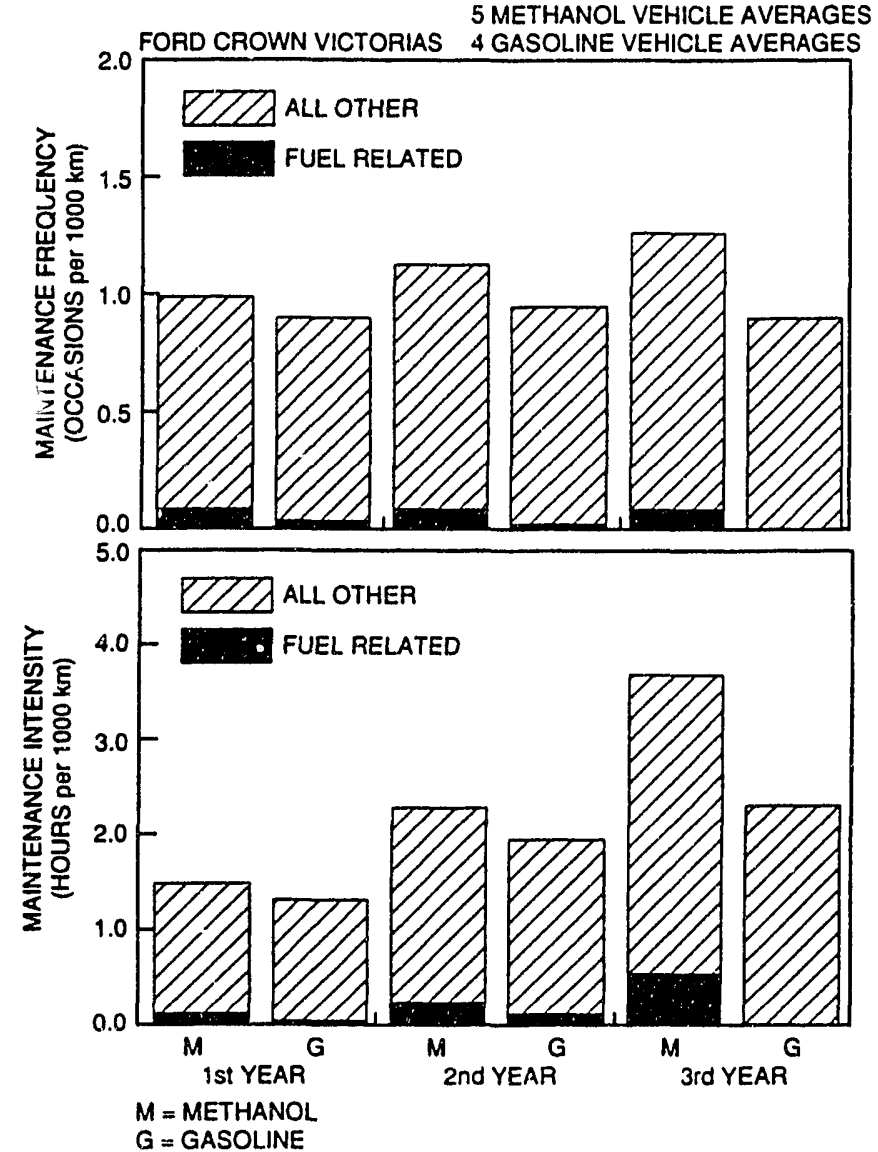

Figure 22. Maintenance frequency and intensity for ANL Fords.
Figure 23 shows similar information for the Buicks at ORNL for their first two years of operation, and similar conclusions can be drawn. In some cases, however, the gasoline vehicles actually required more maintenance in the "all other" category. The maintenance history for the LBL Citations is picesented in Figure 24. Note that for all years at LBL the "all other" categories of both maintenance frequency and intensity are smaller for the gasoline vehicles. This fact reenforces the belief that drivers have a propensity to request service more frequently on an atypical vehicle.

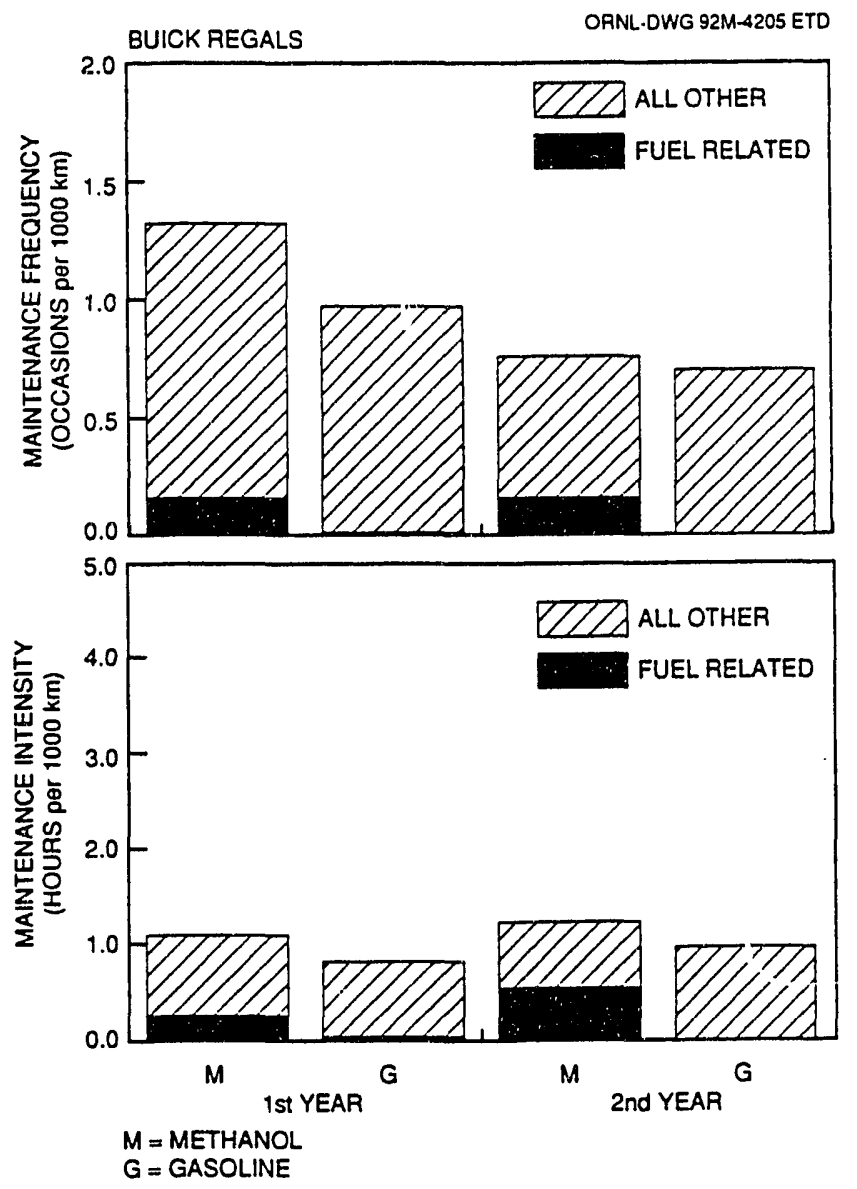

Figure 23. Maintenance frequency and intensity for ORNL Buicks. 


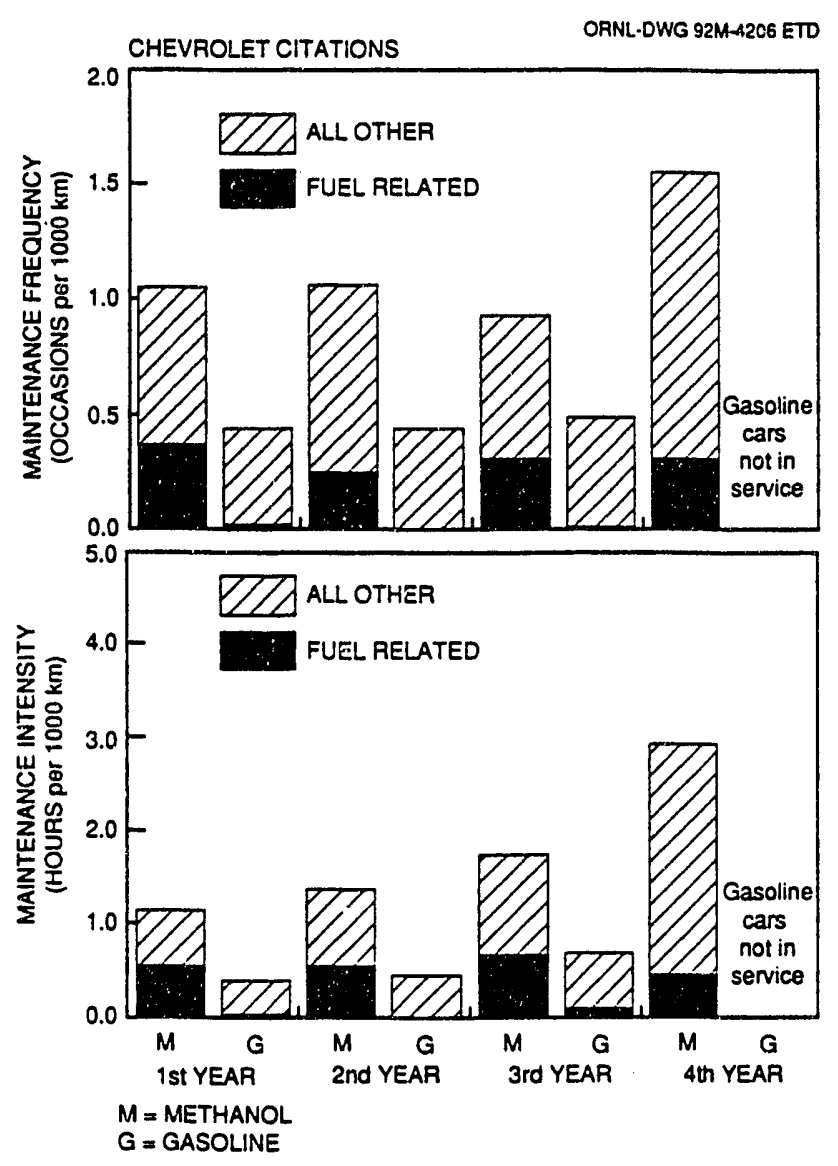

Figure 24. Maintenance frequency and intensity for LBL Chevrolet Citations.

\section{DRIVER SATISFACTION}

\section{Response From Driver Logs}

For the duration of the project, drivers at all three sites were asked to evaluate the vehicles' ease of starting and driveability for each trip by making a check mark under either "Good," "Average," or "Poor" in the vehicle's trip log. Drivers at ANL were also asked to estimate the ambient temperature and to check either " $5^{\circ} \mathrm{F}$ or less," "6 ${ }^{\circ} \mathrm{F}$ to $40^{\circ} \mathrm{F}$," or "Greater than $40^{\circ} \mathrm{F}$." These estimates were intended to give some indication of the vehicles' performance as a function of weather. In general, the gasoline vehicles at all three sites received slightly higher marks than the methanol vehicles, although ratings for both vehicle types were quite high; ease of starting and driveability at all sites were rated as
"Average" or "Good" over $50 \%$ of the time. The cold start systems on the methanol vehicles at ANL apparently performed well. The ratings of ease of starting in colder weather were not highly different from those in milder temperatures. The ORNL fleet showed the greatest seasonal variation in ease of starting ratings, probably as a result of the lack of sophisticated cold-start systems on the methanol vehicles and the freezing and below freezing weather encountered in the Oak Ridge winters. The LBL fleet showed very little seasonal variation in driver satisfaction. Figure 25 shows the average of the first daily ease-of-starting ratings for the methanol vehicles at all three sites as a function of month of the year. Numerical values were assigned to "Good," "Average," and "Poor" so that averages could be computed. The first rating of each day was assumed to be a true "cold start," because the vehicle would have had several hours of "soaking" at the ambient temperature. This might not be universally true in the case of the Fords at ANL, because they were used around-the-clock as security vehicles. The figure shows the average for each month for 2, 3, or 4 years, for the ORNL, ANL, and LBL fleets, respectively. Note that the ORNL Buicks showed the greatest variance, with better ratings in the warmer months and poorer ratings in

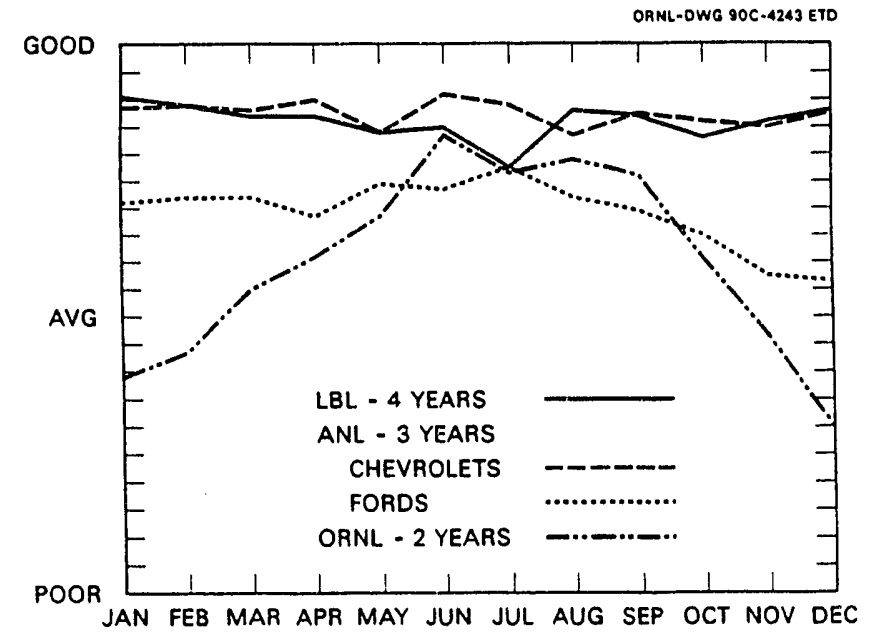

Figure 25. Average ease of starting ratings for first daily start as a function of month. 
colder months. This trend is not as apparent for the LBL Citations, perhaps because of the milder climate, and the ANL Fords and Chevrolets show less variation due to their cold-start systems. Note that the ANL Chevrolets received better ratings than did the ANL Fords. This could be due, at least in part, to the fact that the Chevrolets used a gasoline cold-start system, while the Fords' system used only the M85 fuel. Because the same drivers did not operate both vehicle types at ANL, absolute comparisons should not be made. For the same reason, site-to-site comparisons should not be made.

\section{Response From Driver Surveys}

Survey forms were sent to randomly selected drivers at all three test sites on four separate occasions. The LBL drivers were surveyed twice and the ANL and ORNL drivers were each surveyed once. The overall response rate for all four surveys was $50 \%$. Response from three of the surveys was $50 \%$ or greater, but that from the second survey at LBL was only $39 \%$ (probably a result of loss of interest in the then-three-year-old project). The survey results show percentages of responses to particular questions and any comments given by the respondents. The results of the individual surveys are presented in their entirety in References $1,3,6$, and 9.

In general, the surveys indicated a reasonable level of acceptance of the methanol vehicles at all three sites. In both $\mathrm{LBL}$ surveys over $50 \%$ of respondents said that for the methanol vehicies, the ease of starting, performance during warm-up; and performance when warmed-up were "about the same" as that of the gasoline vehicles. In the first survey, $67 \%$ of respondents at LBL said overall performance was the same, while only $49 \%$ gave this response in the second survey. Ratings of driveability declined with vehicle age, and several drivers at LBL complained that the methanol vehicles stalled frequently or had poor acceleration. In response to these complaints, the vehicles were usualiy sent to the garage for adjustments to the carburetor, which generally constituted nearly half of the "fuel-related" maintenance on the Citations. Similar adjustments were not required on the fuelinjected cars at the other FMF sites. It is not likely that future OEM methanol vehicles will have carburetted engines.

The ANL drivers rated the performance of the methanol Chevrolets as "about the same" or "better" than the gasoline vehicles over $50 \%$ of the time during warm-up and $78 \%$ of the time after being fully warmed up. The Fords were not rated quite as high with ratings of "equal" or "better" twothirds of the time after warm-up, and "equal" only $30 \%$ of the time during warm-up.

Nearly half of the ANL Chevrolet drivers responded that they would consider buying a methanol vehicle and only $17 \%$ of the Ford drivers would consider buying one. Many of the comments received dealt with drivers' concerns over fuel economy (miles per gallon) and range, fuel availability, and driveability in cold weather. Many drivers indicated that they liked the improved performance of the methanol engines, provided that details such as cold-start and range could be addressed.

The Buick Regals at RNL were probably the most well-received vehicles in the FMF. Over $50 \%$ of respondents indicated that the methanol Buicks started about the same as, or better than, the gasoline Buicks. Seventy-three percent of respondents revealed that the methanol vehicles' performance during the warm-up period was the same or better than their gasoline counterparts, while 94\% had these responses for warmed-up operation. The ORNL drivers also indicated high satisfaction with driveability and range (the methanol Buicks had 30 gallon fuel tanks).

The responses from driver surveys and the daily driver logs indicated a generally high level of acceptance of the FMF vehicles. While there were some complaints about driveability, ease of starting, and range, most of these problems can be attributed to the prototype nature of the retrofitted vehicles, or to the relatively small fuel tanks on some of the methanol vehicles. 


\section{SUMMARY AND CONCLUSIONS}

The Federal Methanol Fleet (FMF) Project concluded with the termination of data collection in 1991. Twenty methanol-fueled vehicles were operated in tandem with 19 comparable gasoline vehicles at three DOE sites. These three test sites included the Lawrence Berkeley Laboratory (LBL), the Argonne National Laboratory (ANL), and the Oak Ridge National Laboratory (ORNL). The 39 vehicles accumulated over 2.2 million $\mathrm{km}$ in routine fleet service. Data collected over the years have included vehicle mileage and fuel economy, engine oil analysis, emissions, maintenance, and driver acceptance.

The gasoline vehicles at LBL and ORNL were generally driven 40 to $60 \%$ further per trip than their methanol counterparts, which resulted in 4-17\% higher fuel economy (on an energy basis). Use patterns at ANL were more equitable, and as such, the fuel economies of ANL methanol vehicles were about the same as their gasoline counterparts.

Emissions from some of the gasoline control vehicles and the retrofitted methanol vehicles were measured several times throughout the project. While the emissions of both methanol and gasoline vehicles tended to increase with age, there was evidence of more rapid catalyst degradation on some of the methanol-fueled vehicles. While the methanol vehicles in this project were not optimized for methanol fuel use, it is likely that optimized OEM methanol vehicles will need to employ different catalyst formulations than those used for typical gasoline vehicles.

Evaluations of engine oil from the fleet vehicles have generally indicated higher levels of iron contamination in the oil of the methanol vehicles. Seasonal variations in iron accumulation rate have also been apparent, suggesting that engine wear is increased in colder weather, or under hightemperature, high-load service. While the iron accumulation rates in the methanol vehicles have been as much as an order of magnitude higher than those of their gasoline counterparts in some cases, increased or more apparent engine damage has been difficult to assess. Disassembly of three methanol engines and one gasoline engine from the ANL fleet did confirm some wear patterns typical to methanol engines (such as high cylinder bore wear and corrosion), but contrary to expectations, the gasoline engine had an even higher level of bore wear.

Maintenance records have generally indicated a higher maintenance frequency and intensity for the methanol vehicles at all sites. Fuelrelated maintenance was higher for the methanol vehicles in all cases, and given that the methanol vehicles were retrofitted, or development-type vehicles, this would be expected. It is interesting to note, however, that the fuel-related maintenance could not always account for the higher level of maintenance. In other words, the methanol vehicles were sent to the garage more frequently, but not due to fuel-related problems. The authors believe that drivers were more sensitive to mechanical problems in the more uncommon methanol vehicles, and requested maintenance on occasions that they may have overlooked in a gasoline vehicle.

Drivers at all three fleet sites were asked to fill out a daily driver $\log$ each time they drove one of the FMF vehicles indicating their satisfaction with the vehicle's ease of starting and driveability. Drivers were also surveyed on four different occasions and asked more detailed questions about their satisfaction with the FMF vehicles. Data from the driver logs indicated that the methanol cars were well-received, although the gasoline vehicles generally received better ratings, especially in colder seasons. Respondents to most of the surveys indicated a relatively high level of satisfaction with the methanol vehicles. Typical complaints were related to driveability, ease of starting, and range. Most of these complaints can be attributed to the prototype nature of the vehicles, and the relatively small fuel tanks on most of the methanol vehicles. 


\section{ACKNOWLEDGMENTS}

It is not practicable to name all those involved in the project's success. It was most certainly a team effort. The general interest and enthusiasm of maintenance and other program support personnel at all three DOE sites, personnel at Ford and General Motors, The Bank of America, Alcohol Energy Systems, Michigan Automotive Research Corporation, the Department of Energy, and the drivers themselves, were all contributors to the project's achievements. Grateful acknowledgement is also made to all those who supplied auto parts, lubricating oil, fuel, and laboratory and emissions tests. In particular, Twin City Buick, The University of Tennessee, Lubrizol Corporation, Eastman Chemical Products, The U.S. EPA, Amoco Research Center, and BP America deserve heartfelt thanks. The authors also wish to thank the Publications Division for their assistance in preparation of this and nine previous reports. 


\section{REFERENCES}

1. R. N. McGill, S. L. Hillis, and J. L. Wantland, Results from the First Year of Operation of the Federal Methanol Fleet at Lawrence Berkeley Laboratory, ORNL/TM-10485, Oak Ridge National Laboratory, Oak Ridge, Tennessee, August, 1987.

2. R. N. McGill and S. L. Hillis, Results from the Second Year of Operation of the Federal Methanol Fleet at Lawrence Berkeley Laboratory, ORNL/TM-10815, Oak Ridge National Laboratory, Oak Ridge, Tennessee, August, 1988.

3. R. N. McGill, B. H. West, S. L. Hillis, and J. W. Hodgson, Results from the Third Year of Operation of the Federal Methanol Fleet at Lawrence Berkeley Laboratory, Oak Ridge National Laboratory Report, ORNL/TM-11401, Oak Ridge, Tennessee, December 1989.

4. B. H. West, R. N. McGill, and S. L. Hillis, Results from the Fourth Year of Operation of the Federal Methanol Fleet at Lawrence Berkeley Laboratory, Oak Ridge National Laboratory Report, ORNL/TM-11590, Oak Ridge, Tennessee, August, 1990.

5. R. N. McGill, S. L. Hillis, and R. P. Larsen, Results from the First Year of Operation of the Federal Methanol Fleet at Argonne National Laboratory, Oak Ridge National Laboratory Report ORNL/TM-10816, October, 1988.

6. R. N. McGill, S. L. Hillis, B. H. West, and J. W. Hodgson, Results from the Second Year of Operation of the Federal Methanol Fleet at Argonne National Laboratory, Oak Ridge National Laboratory Report ORNL/TM-11230, August, 1989.

7. B. H. West, R. N. McGill, S. L. Hillis, and J. W. Hodgson, Results from the Third Year of Operation of the Federal Methanol Fleet at Argonne National Laboratory, Oak Ridge National Laboratory Report ORNL/TM-11736, January, 1991.

8. R. N. McGill, B. H. West, S. L. Hillis, and J. W. Hodgson, Results from the First Year of Operation of the Federal Methanol Fleet at Oak Ridge National Laboratory, Oak Ridge National Laboratory Report ORNL/TM-11229, Oak Ridge, Tennessee, June 1989.

9. B. H. West, R. N. McGill, and S. L. Hillis, Results from the Second Year of Operation of the Federal Methanol Fleet at Oak Ridge National Laboratory, Oak Ridge National Laboratory Report ORNL/TM-11622, Oak Ridge, Tennessee, September, 1990.

10. J. W. Hodgson, R. K. Adams, and The Studeni Team, "The University of Tennessee Methanol Corsica - Engineering for Low Emissions, High Performance," SAE paper 902100, Society of Automotive Engineers, Warrendale, Pennsylvania, October 1990.

11. Methanol Innovation: Technical Details of the 1989 Methanol Marathon, SAE publication SP804, Society of Automotive Engineers, Warrendale, Pennsylvania, 1990. 
12. R. P. Larsen, and N. W. Hill, "The 1990 SAE Methanol Challenge: Summary of a Successful Student Design Competition," SAE paper 910570, Society of Automotive Engineers, Warrendale, Pennsylvania, February 1991.

13. "Standards for Emissions from Methanol-Fueled Motor Vehicles and Motor Vehicle Engines," 40 CFR Part 86, Published in Federal Register, Vol. 54, No. 68, April 11, 1989, pp. 1442614613.

14. The Clean Fuels Report, Published by J. E. Sinor Consultants Inc., Niwot, Colorado, Volume 3, No. 4, September 1991, pg. 65.

15. Chamberlin, W. B., and C. L. Gordon, "Methanol-Capable Vehicle Development: Meeting the Challenge in the Crankcase," SAE paper 902152, Society of Automotive Engineers, Warrendale, Pennsylvania, October 1990.

16. S. E. Schwartz, and D. J. Smolenski, "Development of an Automatic Engine Oil-Change Indicator System," SAE paper 870403, Society of Automotive Engineers, Warrendale, Pennsylvania, February 1987.

17. S. E. Schwartz, D. J. Smolenski, and S. L. Clark, "Entry and Retention of Methanol Fuel in Engine Oil", SAE paper 880040, Society of Automotive Engineers, Warrendale, Pennsylvania, February 1988.

18. Personal communication, William B. Chamberlin, Lubrizol Corporation, to Brian H. West, Oak Ridge National Laboratory, February 3, 1992.

19. W. B. Chamberlin, L. L. Bruns, and C. L. Gordon, "Assessing the Lubrication Needs for M85 Fueling Using Short-Trip Field and Engine Dynamometer Tests," SAE paper 922299, Society of Automotive Engineers, Warrendale, Pennsylvania, October 1992.

20. Chamberlin, W. B., and W. C. Brandow, "Lubrication Experience in Methanol-Fueled Engines under Short-Trip Service Conditions," SAE Paper No. 831701, October 1983.

21. Otto, K., R. O. Carter III, C. A. Gierczak, and L. Bartosiewicz, "Steel Corrosion by Methanol Combustion Products: Enhancement and Inhibition," SAE Paper No. 861590, October 1986.

22. Ryan, T. W. III, T. J. Bond, and R. D. Schieman, "Understanding the Mechanism of Cylinder Bore and Ring Wear in Methanol Fueled SI Engines," SAE Paper No. 861591, October 1986.

23. Schwartz, S. E., "An Analysis of Upper-Cylinder Wear with Fuels Containing Methanol," Lubrication Engineering, Volume 42, No. 5, 292-299, May 1986.

24. Buck, W. H., J. R. Lohuis, and J. A. Murphy, "Lubrication Studies in a Methanol-Fueled Spark Ignition Engine," SAE Paper No. 892156, September 1989.

25. Schwartz, S. E., "A Model for the Loss of Oxidative Stability of Engine Oil During Long-Trip Service. Part II. Vehicle Measurements," STLE Preprint 91-AM-6G-3, April-May 1991. 
26. B. H. West, and R. N. McGill, "Oil Performance in a Methanol-Fueled Engine Used in Severe Short-Trip Service," SAE paper 922298, Society of Automotive Engineers, Warrendale, Pennsylvania, October 1992. 


\section{ACRONYMS AND NOMENCLATURE}

$\begin{array}{ll}\text { ANL } & \text { Argonne National Laboratory } \\ \text { CO } & \text { Carbon monoxide } \\ \text { DOE } & \text { Department of Energy } \\ \text { DSC } & \text { Differential scanning calorimeter, a measure of oxidation stability (minutes) } \\ \text { ECM } & \text { Engine control module } \\ \text { EGR } & \text { Exhaust gas recirculation } \\ \text { EPA } & \text { Environmental Protection Agency } \\ \text { FID } & \text { Flame ionization detector } \\ \text { FMF } & \text { Federal Methanol Fleet } \\ \text { FTP } & \text { Federal test procedure (for determining motor vehicle emissions) } \\ \text { g } & \text { Gram } \\ \text { GJ } & \text { Gigajoule (10 Joules) } \\ \text { HCOH } & \text { Formaldehyde } \\ \text { km } & \text { Kilometer } \\ \text { LBL } & \text { Lawrence Berkeley Laboratory } \\ \text { M85 } & \text { Fuel methanol, 85\% methanol, 15\% unleaded gasoline or other hydrocarbon additive } \\ \text { mpg } & \text { Miles per gallon } \\ \text { NO } & \text { Oxides of nitrogen (nitrogen dioxide, NO }{ }_{2} \text {, and nitric oxide, NO) } \\ \text { OEM } & \text { Original equipment manufacturer } \\ \text { OMHCE } & \text { Organic material hydrocarbon equivalent } \\ \text { ORNL } & \text { Oak Ridge National Laboratory } \\ \text { TBN } & \text { Total base number, a measure of alkaline reserve }\end{array}$


ORNL/TM-12278

Dist. Category UC-334

\section{INTERNAL DISTRIBUTION}

1. M. S. Bronzini

2. R. S. Carlsmith

3. N. Domingo

4. R. L. Graves

5. J. E. Jones, Jr.

6. T. S. Kress

7-16. R. N. McGill

17-31. B. H. West

32. Central Research Library

33. Document Reference Section

34-35. Laboratory Records

36. Laboratory Records (RC)

37. ORNL Patent Office

38. Technical Library $\mathrm{Y}-12$

\section{EXTERNAL DISTRIBUTION}

1. J. R. Allsup, Office of Transportation Systems, CE 332, 1000 Independence Ave., U.S. Department of Energy, Washington, DC 20585

2-11. Brent Bailey, National Renewable Energy Laboratory, 1617 Cole Boulevard, Golden, Colorado 80401-3393

12. Vittoria Battista, Project Engineer, Transport Canada, Canada Bldg, Floor 13, Ottawa, Ontario K1AON5, Canada

13. R. L. Bechtold, Project Manager, Mueller Associates, 1401 South Edgewood Street, Baltimore, MD 21227

14. G. L. Borman, Professor, University of Wisconsin-Madison, 1500 Johnson Drive \#119, Madison, WI 53706

15. J. J. Brogan, Department of Energy, Office of Energy Systems Research, CE 142, Washington, DC 20585

16. W. B. Chamberlin, Lubrizol Petroleum Chemicals Co., 29400 Lakeland Blvd., Wickliffe, $\mathrm{OH} \quad 44092-2298$

17. Granger Chui, Ford Motor Co., Box 2153, Dearborn, MI 48121

18. Wendy Clark, Automotive Testing Laboratories, Inc., PO Box 289, East Liberty, OH 43319 
19. Richard Earle, Greenbranch Enterprises, Inc., PO Box 2486, Key Largo, FL 330377486

20. D. P. Gardiner, Research Officer, Department of Mechanical Engr, Royal Military College of Canada, Kingston, Ontario K7K5LO

21. John Garbak, Office of Transportation Systems, CE 332, 1000 Independence Ave., U.S. Department of Energy, Washington, DC 20585

22. Pier-Paolo Garibaldi, Chairman, Committee of Alternative Fuels, International Energy Agency, Ecofuel, Viale Brenta 15, Milano, Italy 20139

23. Steve Goguen, Office of Transportation Systems, CE 332, 1000 Independence Ave., U.S. Department of Energy, Washington, DC 20585

24. Curtis L. Gordon, Lubrizol Petroleum Chemicals Co., 3000 Town Center, Suite 1340, Southfield, MI 48075-1201

25. M. E. Gunn, Jr., Department of Energy, Office of Energy Systems Research, CE 142, Washington, DC 20585

26-30. S. L. Hillis, Office of Technology Brokering, Suite 211 Aconda Court, 802 Volunteer Blvd, Knoxville, TN 37996

31-35. J. W. Hodgson, Mech. \& Aero. Engineering, University of Tennessee, Knoxville, TN 37916

36. Mike Jackson, Manager, Alternative Fuels, Acurex Corporation, Environmental Systems Division, 485 Clyde Avenue, P.O. Box 7044, Mountain View, CA 94039

37. Bernie A. James, Senior Engineer, Alternative Fuels, Energy, Mines \& Resources Canada, 580 Booth Street, Ottawa, Ontario, Canada KlA OF4

38. Martha Kass, Department of Energy, Oak Ridge Operations, P.O. Box 2009 Bldg 4500-N, Oak Ridge, TN 37831

39. Lionel J. King, Sypher: Mueller International Inc., 130 Slater Street, Suite 1025, Ottawa, Ontario K1P 6E2

40. Kenneth Knapp, Chief, Mobile Sources Emissions Branch, U.S. Environmental Protection Agency, MD-46, Research Triangle Park, NC 27111

41. R. P. Larsen, Argonne National Laboratory, 9700 South Cass Avenue, Argonne, IL 60439

42. Alexander Lawson, Manager, Centre for Alternative Fuel Utilization, Ontario Research Foundation, Sheridan Yäk Research Community, Missisauga, Ontario, Canada I 4K $1 \mathrm{B3}$

43. Ray Lewis, President, American Methanol Institute, 815 Connecticut Ave. NW, Suite 800, Washington, DC 20006 
45. Roberta Nichols, Ford Motor Co., 2000 Rotunda Dr., Dearborn, MI 48121

46. D. J. Patterson, ME/AM, University of Michigan, 309 Automotive Laboratory, Ann Arbor, MI 48109

47. Claes Pilo, Chairman, Ecotraffic AB, Gamla Brogatan 29, Stockholm, S-111 20 Sweden

48. David Rogers, Office of Transportation Systems, CE 332, 1000 Independence Ave., U.S. Department of Energy, Washington, DC 20585

49-58. J. A. Russell, Office of Transportation Systems, CE 332, 1000 Independence Ave., U.S. Department of Energy, Washington, DC 20585

59. Shirley E. Schwartz, Fuels and Lubricants Department, General Motors Research Laboratories, Warren, MI 48090-9055

60. Ken Stamper, National Renewable Energy Laboratory, 1617 Cole Boulevard, Golden, Colorado 80401-3393

61. Richard Wares, Office of Transportation Systems, U.S. Department of Energy, Forrestal Bldg. CE 332, 1000 Independence Ave., Washington, DC 20585

62-71. Office of Scientific and Technical Information, P.O. Box 62, Oak Ridge, TN 37831

72. Office of Assistant Manager for Energy Research and Development, 200 Administration Road, Federal Building, Oak Ridge, TN 37830 

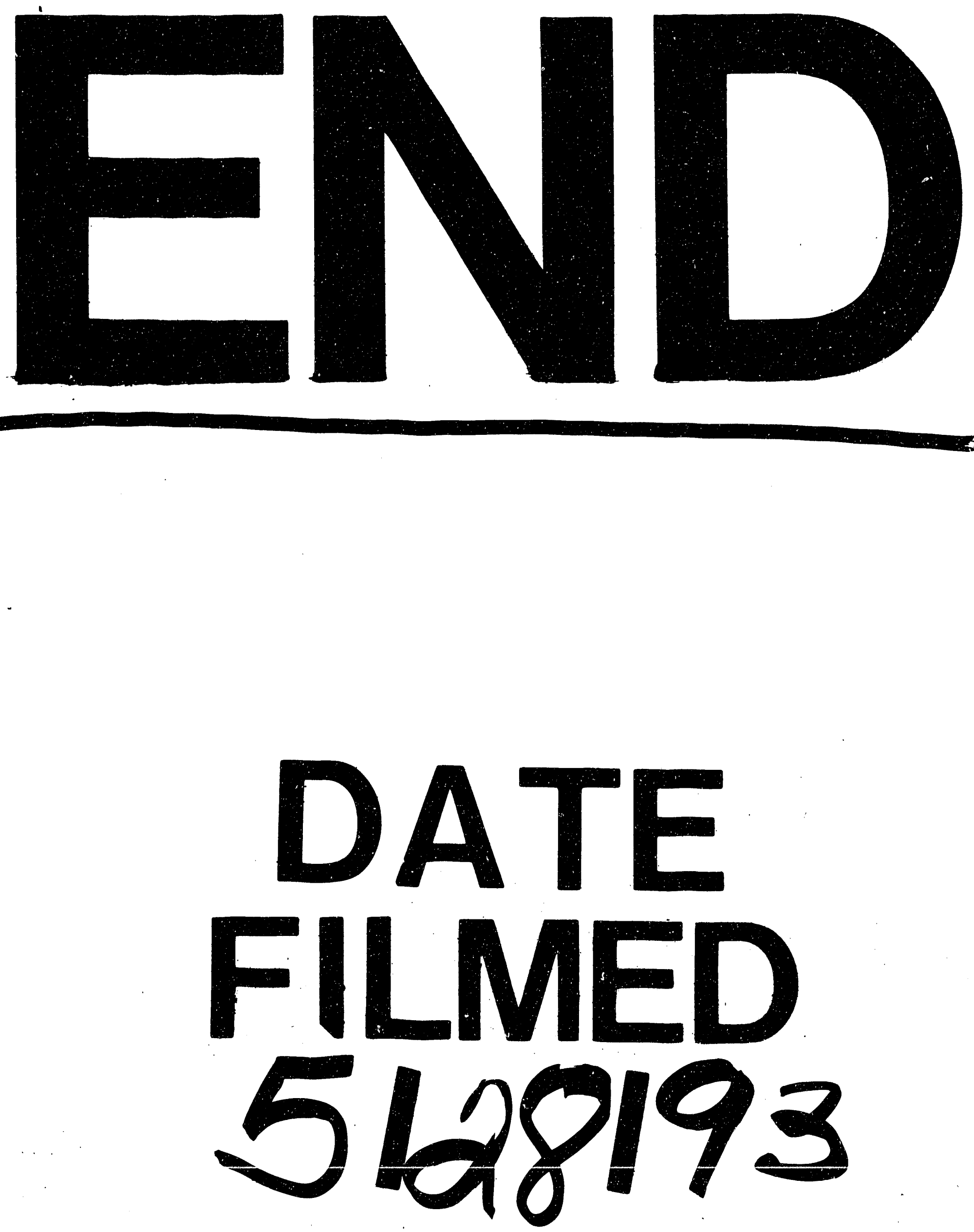